\title{
Provenance of Chalk Tesserae from a Roman Town House in Vine Street, Leicester
}

\author{
By A. Tasker, I.P. Wilkinson, M. Williams, M. Morris, \\ N. Cooper and M. G. Fulford
}

\begin{abstract}
Fourth century $\mathrm{AD}$ chalk tesserae from Roman Leicester (Ratae Corieltavorum) yield rich microfossil assemblages that identify a biostratigraphical age of Cretaceous Late Cenomanian to Early Turonian. The nearest chalk outcrops to Leicester lie in Hertfordshire, Lincolnshire, Yorkshire and north Norfolk, indicating that the material for the tesserae must have been sourced remotely and transported to Ratae. Superimposing the Roman road network onto a map of the relevant Chalk Group distribution provides a guide to possible sources. A process of evaluation identifies Baldock in Hertfordshire and Bridlington in Yorkshire as the most likely sources for the Leicester tesserae.
\end{abstract}

Keywords: Roman mosaics; Leicester; chalk tesserae; geological provenance; foraminifera. 


\section{INTRODUCTION}

Excavations of urban and rural sites across Britain dating to the Roman occupation (43-410 AD) have revealed many mosaics of high quality and some whose workmanship is exceptional, as a recentlycompleted corpus of all known mosaics from Britain illustrates ${ }^{1}$. The wealth of abstract pattern and figurative detail contained in these mosaics has excited considerable discussion about their artistic composition and iconographic interpretation ${ }^{2}$ and also speculation as to the existence of fourthcentury groups of mosaicists based on the identification of regional shared stylistic characteristics ${ }^{3}$. However, there are still many practical questions concerning the manufacture of the mosaics that remain unanswered. In particular, we have little knowledge about the way in which tesserae (the small cut and tailored stones from which the mosaic was assembled) were sourced and transported. This study investigates the provenance of chalk tesserae from Leicester (Ratae Corieltavorum).

There were sound reasons for choosing to study material from Leicester. Firstly, the town occupied a central position in the Roman province of Britannia. This was central not only in terms of location, although Ratae is situated in almost the exact centre of the province, but also in economic and developmental terms, as the town lay (as it were) in the mid lands between the 'militarised north' and the 'civilised south'. This made the possibility of contributing to the post-excavation analysis of the first complete Town House to be uncovered in Ratae an interesting prospect. Secondly, there are no chalk outcrops within easy reach of the town, which means that any chalk artefacts recovered from excavation must have been transported. Ratae had good road and river communications with the rest of the province and it was thought that this would enable some light to be shed on the movement of mosaic materials. Thirdly, there was an availability of chalk tesserae from several different archaeological levels in the Town House. All these factors combined to make material from Leicester a suitable candidate for study.

Chalk has a distinctive microfossil signature which can be utilised to determine its biostratigraphical age and thus, in many cases, its source. Narrowing down the provenance of the chalk to particular areas enables conclusions to be drawn about the origin, transportation and distribution of the tesserae. Tesserae that can be traced to a particular level in an excavation are particularly useful in this respect, in that they are likely to be dated, at least approximately, by the wider archaeological 
context in which they were found. This information can then be used to determine whether the provenance of the raw material varied through time.

A pilot study demonstrating the validity of this 'microfossil signature' technique examined chalk tesserae from Silchester (Calleva Atrebatum) ${ }^{4}$. The excavation furnished several mosaics dating from the first to the fourth centuries $A D$. The chalk tesserae yielded an assemblage of microfossils (ostracods, foraminifera and coccoliths) dating to the Late Cretaceous. This eliminated local sources of chalk, which were older in date, and pointed instead to an origin in the English chalk downlands, which suggested that the mosaicists working in Calleva had imported their tesserae from Dorset, a source of other lithologies used in the mosaics. More recently, microfossils have been used to show that local chalk was used in mosaics at Brading Roman Villa on the Isle of Wight ${ }^{5}$. Here we use microfossils to reconstruct the biostratigraphical age of chalk tesserae used in Roman Leicester and refer to the distribution of the Chalk Group in England to suggest likely areas of provenance for the tesserae.

\section{METHODOLOGY}

The need for more and better information on the geographical origin of mosaic materials has been acknowledged for some time ${ }^{6}$ and this has led to a growing recognition of the contribution that geology can bring to archaeology in the field of provenance studies. In recent years, the provenance of tesserae and sculptural material has been investigated using microfacies analysis ${ }^{7}$, petrological analysis $^{8}$, a combined approach using microfacies, petrological and geochemical analysis ${ }^{9}$, and microfossil analysis ${ }^{10}$.

These approaches have contributed much to our understanding of the use of raw materials in the manufacture of tesserae. For example, boulders and pebbles of Mesozoic carbonates and sandstones found locally in Pleistocene and Holocene glacial sediments have been shown to be the source of raw material used to manufacture bichrome (black and white) mosaic tesserae from two villas close to Augsburg (Augusta Vindelicum) in Bavaria ${ }^{11}$. Similarly, an early third century polychrome mosaic from Kraiburg in Bavaria was found to contain coloured tesserae cut from Jurassic and Cretaceous sedimentary deposits found in local Pleistocene fluvioglacial deposits ${ }^{12}$. 
Dolomitic cementstone and burned clay sourced from the Upper Jurassic Kimmeridge Clay Formation in Dorset contributed the raw material for a large number of tesserae from mosaics found at Silchester ${ }^{13}$ and the use of these and other lithologies from the same geographical area in the manufacture of pottery, tesserae, shale goods and sculptural items found in archaeological sites across south-east England provides strong evidence for a geomaterials industry based in the PoolePurbeck area of Dorset from the first century $A D$ onwards ${ }^{14}$. Finally, geochemical and microfacies analysis of materials used in the manufacture of first-century sculpture found in Roman Britain has also recorded the use of Caen limestone and similar freestones from the Jurassic, Upper Cretaceous and Tertiary periods imported from widely separate outcrops in northern and central France ${ }^{15}$. This study focuses on the contribution to provenance studies that can be made using biostratigraphy based on microfossil analysis.

\section{MICROFOSSILS AND PROVENANCE}

The principle of biostratigraphy is not new. Similarities and differences in fossil fauna and flora have been used to characterise rock successions since the pioneering work of the engineer geologist William 'Strata' Smith in the early nineteenth century ${ }^{16}$. This powerful methodology has enabled the correlation and relative dating of rock successions throughout the Phanerozoic and provided a framework for the understanding of evolutionary lineages and global environmental change. Using the fossil content of rocks to characterise and so correlate particular strata is a widely-used technique in geology.

Microfossils have proved themselves particularly useful in this respect. Their very small size (generally $<1 \mathrm{~mm}$ ) enables them to be recovered from small samples, a useful characteristic when dealing with tesserae, which are typically sized between $0.5-2.0 \mathrm{~cm}^{3}$. In general, the groups of organisms that are preserved as microfossils also evolve rapidly, are geographically widespread, can be extremely abundant and are found in a wide variety of sedimentary rock types ${ }^{17}$. As a result, there is growing recognition of the research potential of microfossils to the study of inorganic archaeological materials ${ }^{18}$. The microfossils found in chalk rock units - principally ostracods, foraminifera and nannofossils - have been studied particularly closely because of their usefulness in correlating strata between regions and because chalk formations may be potentially oil bearing. Correlating strata across regions has also led to the concept of foraminiferal biozones: biostratigraphic intervals based on the presence of particular species or assemblages of 
foraminifera. These faunal differences can be used to provenance chalks and are the basis of the approach to provenance taken in this paper.

\section{ROMAN LEICESTER AND THE VINE STREET TOWN HOUSE}

Leicester (Ratae Corieltavorum) is sited at a crossing point of the River Soar and this geographical advantage is likely to have contributed to its early development as an important Late Iron Age settlement: by the end of the first century $\mathrm{BC}$, the community was prosperous enough to be importing pottery from Gaul and the Mediterranean ${ }^{19}$. The settlement appears to have been a local centre for the Corieltavi, whose coins are found here, most recently amongst a series of hoards found in a shrine context some $15 \mathrm{~km}$ to the south east at Hallaton ${ }^{20}$. It is possible that the strategic importance of the settlement and its river crossing point made Ratae an early military objective for the invading Roman army, as a small Roman fort appears to have been established on the west bank of the river to control the crossing ${ }^{21}$ and although it is not known whether the tribal groupings constituting the Corieltavi were amicable, ambivalent or antagonistic towards the Romans, there is a suggestion that the invading forces may not have been welcomed by all $^{22}$. A gridded town plan was laid out early in the second century $A D$, probably coincident with the town becoming a civitas capital, but the main phase of civic building did not occur until later: a stone forum and basilica were built under Hadrian (117-138 AD), the Jewry Wall public baths under Antoninus Pius (138-161 AD) and the market hall or macellum not until the late second century ${ }^{23}$. Mosaics dating from the second to the fourth century $A D$, some of very high quality, have been recorded from Ratae, the greatest density being found in the west of the tow ${ }^{24}$ from houses overlooking the river. This may indicate that the western half of the civitas was more prosperous than the east ${ }^{25}$. Figure $1(a)$ shows the location of Leicester in the UK and the town plan of Ratae.

In 2004-6, the University of Leicester Archaeological Service (ULAS) carried out the largest excavation ever undertaken in Leicester as part of the new Highcross retail development ${ }^{26}$. The excavation took place in the vicinity of Vine Street and provided a rare opportunity to investigate in detail the building history of private domestic and commercial properties in one of the more peripheral insulae of the Roman town (Insula V). In all, ten Roman buildings situated in the northeast corner of the settlement and dating from the late first to the late fourth centuries AD were 
excavated. The excavation revealed a history of modest development during the first and second centuries $A D$, followed by a period of active construction in the third and a degree of decline in the fourth. The second-century buildings found on the site were not without merit. Tesserae and decorated wall plaster containing cinnabar found among debris associated with one of these buildings (Building D, later incorporated into the Town House) imply that it had a superior status and there is good evidence for suggesting that that the central room of this building was the source of the second-century geometric mosaic found in 1839 and which is now housed in the Jewry Wall Museum in Leicester ${ }^{27}$.

A major phase of renewed construction in Insula $V$ at the beginning of the third century led to the above building and two others on the same site being remodelled into a single structure by the addition of a north range. The new north range was connected to the three existing buildings by a peristyle corridor that surrounded an internal courtyard and gave access to suites of rooms within the new complex. It was partially provided with a hypocaust system and contained a central apsidal room, suggestive of a formal reception room, which was set opposite a possible entrance hall in the southern range across the courtyard. This third-century remodelling created a substantial courtyardstyle town house some $39 \mathrm{~m} \times 40 \mathrm{~m}$ square (the Vine Street Town House). The Town House occupied the whole south-east corner of the insula, providing it with two road frontages. A plan is given in Figure 1 (b).

Apart from some modest improvements made in the early-to-mid third century, the Town House appears to have undergone no further major structural alterations. Successive resurfacing of floors throughout the building indicates that it was occupied continuously for around 150 years until its abandonment as a dwelling in the mid-fourth century. There is no evidence of sumptuous decoration, but some fragments of coarse mosaic flooring were found in situ in the peristyle corridor of the eastern range. These are contextually dated to the early fourth century AD. Enough tessellation remains to show that the simple design consisted of red tile tesserae set into a background of blue-grey sandstone ones, either in multiple stripes or in a grid pattern. The red-onblue grid pattern is similar to other geometric mosaics found in Leicester and dating to the same period, such as those found at the Norfolk Street (Cherry Orchard) villa, sited about $1 \mathrm{~km}$ outside the Roman town on the west bank of the river $^{28}$, and there are similarities to other fourth-century mosaics found at Tixover and Thistleton Dyer in Rutland ${ }^{29}$, although in these villas the red grid is laid 
on a buff background. Sufficient further quantities of residual blue-grey and red tesserae were recovered from elsewhere at this level in Vine Street to suggest that the north range suite of rooms and its associated corridor may have been similarly tessellated, and a Small Find of intact mosaic consisting of several rows of smaller tesserae (SF 1084, discussed below) indicates that the building may have housed a finer quality mosaic in at least one room. Unfortunately, the north range appears to have been deliberately demolished in the mid-fourth century, thus removing any evidence for mosaics from the rooms most likely to house them, and the Town House also appears to have been abandoned as a private dwelling around this time. There is evidence that some rooms continued to be used as workshops for a short time longer, but the building seems to have become derelict by the end of the fourth century.

\section{THE VINE STREET TOWN HOUSE TESSERAE}

The tesserae examined in this study came from four levels of redeposited and unsorted material (Vine Street A, B, C and D) found in Room 6 in the far south-western corner of the Town House ${ }^{30}$. The Vine Street B tesserae had been re-used, along with ceramic tile and sandstone fragments, to provide the substrate for a new floor in Room 6 during a major phase of resurfacing in the early to mid fourth century. The Vine Street $A$ and $C$ tesserae were taken from two piles of reclaimed building material which had been left in the northern end of Room 6, apparently as salvage, during the final usage of the building in the mid to late fourth century. The Vine Street $D$ tesserae were sampled from the fine mosaic Small Find SF 1084 mentioned above. This had been picked off the floor of Room 6 and consisted of three rows of small white chalk tesserae and one row of small dark blue-grey limestone tesserae. The location of Room 6 in the Town House is shown in Figure 1 (b).

The Vine Street tesserae examined in this study were all taken from redeposited material, so although the time of their re-deposition relative to the age of the building may be inferred from the archaeological context, it is not possible to know with any certainty either when or where the mosaics from which they were salvaged were laid. However, it is possible to make some assumptions. The simple tessellated design of the surviving peristyle mosaic appeared to use only blue-grey and red tesserae, which suggests that the white chalk tesserae used for this study came from elsewhere in the Town House. Also, the tesserae examined included finer material: some of the Vine Street A material was less than $0.4 \mathrm{~cm}^{2}$ in size, and the Vine Street $C$ tesserae were all small $\left(<1.0 \mathrm{~cm}^{2}\right)$ and contained a number of thin triangular shapes, indicating that they had been used for 
more detailed tessellation. This suggests that the Vine Street $A$ and $C$ tesserae found in Room 6 may originally have been laid in one of the principal rooms in the north range and were salvaged for reuse when this was demolished in the mid-fourth century. If this is so, the cemented tesserae of the Vine Street $D$ small find may be a fragment of a finer-quality mosaic originally laid in one of the formal rooms.

Unfortunately it is not possible to ascertain from the archaeological evidence when any such finerquality mosaics might have been laid. The north range was demolished in the mid-fourth century and post-Roman truncation has removed levels to below that of the Roman floor. However, the date can be modestly constrained by recognising that any mosaics laid at the time of the construction of the north range would date to the early third century, whilst any contemporaneous with the tessellation of the peristyle corridor would date to the early fourth. Arguments for the later date might include the reasonable assumption that the tessellation in the north range and its associated corridors was laid at the same time, and that the tesserae found in Room 6 had been carefully salvaged and collected; any mosaics in the north range laid in the early fourth century would not have been in place for longer than about 20 or 30 years before the range was demolished and the material might therefore have been thought particularly worth saving.

\section{RECOVERING MICROFOSSILS FROM THE TESSERAE}

Sample tesserae from three of the four levels of the Vine Street excavation (Vine Street A, B and C) were crushed and processed individually, using a variety of techniques. As the Vine Street A tesserae were relatively soft, two of them were simply crushed and examined unprocessed, but this technique was not successful in extracting microfossils and so the remaining tesserae from Vine Street A were processed by soaking them in white spirit for 30 minutes and then boiling them in sodium hexametaphosphate. In contrast the Vine Street B and C tesserae, which were generally harder, were processed by a freeze-thaw method using sodium sulphate decahydrate (Glauber's Salt), as results from a trial of processing methods suggested that the freeze-thaw method was a more successful technique than the white spirit method for extracting microfossils from harder chalks ${ }^{31}$. In addition, polished thin sections were made from tesserae from all three levels. However, as consistently good microfossil identification results were obtained only from thin section analysis, this was the only method adopted for the Vine Street D mosaic fragment, six of whose tesserae (five white chalk and one blue limestone) were removed for this purpose. 
In total, 36 tesserae from Vine Street were examined, of which two (VS A15 and A16) yielded no microfossils and a third (VS B05) was crushed sacrificially in order to demonstrate the strong smell of bitumen released on disintegration (Table 1).

The samples of loose tesserae varied considerably in size, as might be expected of reclaimed but unsorted material. The Vine Street A tesserae varied the most in size, the smallest triangular tesserae having sides less than $0.4 \mathrm{~cm}$ in length whilst the largest coarse tessera was a rectangular $2.5 \times 3.0 \mathrm{~cm}$. The Vine Street B tesserae were square, typically sized between 1.5 and $2.0 \mathrm{~cm}^{2}$, similar to those used for coarse tessellation. In contrast, the Vine Street $C$ tesserae were all small $\left(<1.0 \mathrm{~cm}^{2}\right)$ and the sample contained a number of thin triangular shapes. The cemented Vine Street $D$ tesserae were also small, typically between about 1.0 and $1.3 \mathrm{~cm}^{2}$. The samples also varied in hardness, the Vine Street A tesserae being generally softer (easier to crush) than either the Vine Street B or C tesserae. The Vine Street B tesserae were grey, smelled strongly of bitumen when crushed and were splintery in texture when processed. They were classified as a calcareous mudstone and found to yield few microfossils.

\section{BIOSTRATIGRAPHICAL ANALYSIS}

The distribution of species of foraminifera within the Upper Cretaceous Chalk Group is well known ${ }^{32}$ and this knowledge has enabled a sequence of Foraminiferal Biozones to be developed by Wilkinson through the application of existing biostratigraphical schemes to high-resolution mapping carried out by the British Geological Survey $(B G S)^{33}$. Foraminifera recovered from the Vine Street tesserae were compared to this dataset. Details of the tesserae examined and the foraminifera identified appear in Tables 2-5. Figure 2 shows thin-section images of some of the key species identified. Figure 3 shows the Upper Cretaceous (Cenomanian and Turonian) lithostratigraphy and biostratigraphy for chalks of northern and southern England and also the frequency and abundance of the algal sphere Pithonella sphaerica in the early Late Cretaceous for chalks of southern England. The shaded area in Figure 3 represents the stratigraphic age range for the microfossils recovered from the Vine Street chalk tesserae, based on the known evolutionary ranges of the index species recovered from the samples. An analysis of the results for each of the levels appears below. 


\section{VINE STREET A}

Thirteen chalk tesserae from Vine Street A were processed, two tesserae were examined unprocessed and two more were thin sectioned. All the planktonic foraminifera viewed or recovered were simple, non-keeled forms, mostly of Hedbergella (Table 2). The absence of keeled species suggests the fauna date to the Cenomanian. This is supported by the common occurrence of the algal sphere Pithonella sphaerica, whose numbers increase noticeably during the Cenomanian to reach flood proportions in the Late Cenomanian and Early Turonian, as shown in Figure 3. However, although several samples of the Vine Street A material were highly fossiliferous, index species used in biostratigraphical zonation were not found in the tesserae examined.

\section{VINE STREET B}

The Vine Street B tesserae broke into hard and splintery grey fragments and released a strong smell of bitumen when crushed. The sample taken for thin section analysis also released a similar smell of bitumen when cut. However, samples of the fragments reacted positively when tested with cold dilute hydrochloric acid. It would appear therefore that the Vine Street B tesserae had been cut from a calcareous mudstone rather than from a chalk. A very few indeterminate microfossils were recovered from the calcareous mudstone but these could not be positively identified as foraminifera (Table 3). This sample was therefore not considered further.

\section{VINE STREET C}

Six samples from the Vine Street $C$ tesserae were processed. One of these (C02) was a soft and creamy-white chalk from which foraminifera were recovered, but unfortunately these were poor in quality and none could be identified with certainty. However, a thin section cut from a second and harder chalk tessera (C07) proved to be highly fossiliferous. The remaining five tesserae appeared chalky, but splintered into blue-grey fragments on processing, the chalky appearance being due to a surface covering of lime mortar masking a dark blue-grey limestone. No foraminifera were recovered from these five tesserae or their mortar. However, the similarity between the two rock types found in this sample (chalk and a blue-grey silty limestone) and those found in the mosaic fragment described below (Vine Street D) suggest that the Vine Street $C$ tesserae might have been salvaged from the same mosaic as the Small Find 1084. 
The microfossils identified from the Vine Street $C$ thin section (Table 5) consisted of keeled and nonkeeled planktonic foraminifera and an abundance of the algal sphere Pithonella sphaerica. There were noticeably few benthonic foraminifera. The non-keeled planktonic foraminifera were represented by long-ranging species such as Hedbergella delrioensis, $H$. brittonensis and Heterohelix reussi. However, the keeled planktonic foraminifera identified from the thin section included the index species Dicarinella hagni, whose appearance is limited to BGS Foraminiferal Zones 6-9 (sensu Wilkinson, 2000) which cover the period from the late Cenomanian to the early Turonian. The thin section also revealed most noticeably Pithonella sphaerica in flood proportions. Pithonellid blooms are characteristic of several stages in the Late Cretaceous, of which the earliest is in the early Turonian $^{34}$. The pithonellid and planktonic foraminiferal evidence would therefore suggest an early Turonian date for these tesserae. This is supported by evidence from the few benthonic foraminifera recovered, which include, as well as the long-ranging Lenticulina rotula, the occasional specimen of the benthonic foraminifer Gavelinella cf G. berthelini, which is found particularly in the Cenomanian to Turonian.

\section{VINE STREET D}

Polished thin sections were made from six tesserae (five of white chalk and one of dark blue-grey limestone) extracted from a mosaic fragment (SF 1084) found in Room 6. Only bivalve fragments were seen in the limestone sample (D06) and so this will not be considered further. The five chalk sections all contained microfossils: these consisted of keeled and unkeeled planktonic foraminifera and variable numbers (rare to flood proportions) of the algal sphere Pithonella sphaerica. The unkeeled foraminifera included long-ranging species such as Hedbergella brittonensis, $H$. delrioensis and Heterohelix species, including $H$. moremani. The keeled foraminifera included the index species Marginotruncana marginata, which first appears at the base of BGS Foraminiferal Biozone 8 , in the latest Cenomanian. However, it was noticeable that only one species of benthonic foraminiferid could be identified (Gavelinella sp.). In contrast, the algal sphere Pithonella sphaerica was found in all of the chalk thin sections, occurring rarely in one (D02) but either commonly or in flood proportions in two others (D04 and D03 respectively). Occasional $P$. ovalis was also found in one thin section (D05). The appearance of Marginotruncana marginata constrains the date of this sample to the very Late Cenomanian or Early Turonian. 


\section{DISCUSSION}

The underlying solid geology of the Roman city of Ratae Corieltavorum comprises the Triassic Mercian Mudstone Group sedimentary deposits, which to the east of the modern city are succeeded by younger Jurassic limestones and mudstones that form a series of rolling hills stretching towards the town of Peterborough in north Cambridgeshire. Unlike at Brading on the Isle of Wight ${ }^{35}$ or at Roman Silchester ${ }^{36}$ there is no immediate source of rock from the Cretaceous Chalk Group in or around Leicester, nor are Chalk Group erratics reported from the Quaternary till deposits of Leicestershire, although small fragments of chalk occur locally in the glacial till of the Oadby Member. However, the taxa identified in the Oadby Member chalk fragments are Coniacian to Santonian in age and so date to the middle Late Cretaceous ${ }^{37}$ and the fragments themselves are almost certainly too small and too few to have been used systematically as a source of chalk for tesserae, as Figure 4 demonstrates. Taken together, these factors strongly suggest that the chalk used to manufacture the Vine Street mosaics has a remote source.

The long-distance transport of chalk need not surprise us. Wilkinson et al. ${ }^{36}$ noted the likelihood of chalk having been transported from the south coast of Britain $100 \mathrm{~km}$ northwards to Roman Silchester (Calleva Atrebatum), despite local chalks outcropping in the near vicinity of the town: a decision that may have been made on grounds of quality, as long-distance transport must have incurred some expense and at least a modicum of inconvenience. However, the long distance overland transport of bulky items within the province seems always to have been a possibility. One of the earliest known examples of fine freestone carving in Britannia, the Claudian tombstone of the auxiliary cavalryman Longinus Sdapeze (RIB 201), was carved from a Middle Jurassic oolitic limestone (Painswick Stone) that had been transported some $230 \mathrm{~km}$ from the Gloucestershire Cotswolds to the legionary garrison at Colchester in Essex ${ }^{38}$. Rubble from the Temple of Claudius Precinct at Colchester has also revealed a sample of Middle Jurassic Lincolnshire Limestone and one of the paving stones found at the Precinct is a possible example of Lower Jurassic Ham Hill sandstone from Somerset ${ }^{39}$. Hayward suggests that the long distances travelled by these raw materials could reflect either the involvement of the military in their provision or a lack of information during the earliest years of the occupation on the availability of more local sources of suitable stone. However, Painswick Stone does take a fine polish, and Haywood admits that its appearance during the first 
century $A D$ in several non-military contexts in Silchester, Caerleon and London might also reflect a choice based on this quality ${ }^{40}$; so choice might always have been a factor in selection.

The presence of tesserae at Vine Street cut from chalks dating to both the Late Cenomanian and Early Turonian stages suggests that the tesserae may have originated from a single source, as these stages are contiguous in the stratigraphical column. A possible site might be a quarry that exposed the boundary between the two stages. However, the nearest Late Cenomanian-Early Turonian stage chalk outcrops to Leicester are found at some considerable distance: in the Lincolnshire Wolds, about $110 \mathrm{~km}$ to the north east; in north Norfolk, some $120 \mathrm{~km}$ almost due east; in the Hertfordshire Chilterns, about $95 \mathrm{~km}$ to the south east; and on the West Berkshire Downs, around $140 \mathrm{~km}$ to the south. Chalks from these two stages are also widely found along the south coast of England, from Beer in south-east Devon to Dover in Kent (Figure 5). These last locations are obviously at greater distances from Leicester ( $>300 \mathrm{~km}$ ), but as we have seen already, transport over such distances is not impossible.

From a geographical perspective, therefore, the potential source areas for the Vine Street chalk tesserae are widely spread. However, it is possible to use archaeological data to narrow down the geographical possibilities. It is clear from the mass of archaeological reports, watching briefs, fieldwalking surveys and Heritage Environment Records (HERs) comprising the grey literature of RomanoBritish archaeology that the casual digging of pits for the local extraction of chalk around settlements was a common practice. However, there are places in which the archaeological evidence appears to show that the extraction of chalk was deliberate and systematic and on a large enough scale to suggest that actual quarrying was taking place. Superimposing the Roman road network of the second and later centuries AD onto a map of the UK showing Chalk Group outcrops of the relevant stages highlights potential areas of investigation for such quarrying activities and also likely overland transportation routes for their chalk products (Figure 5). The following sections of this paper therefore attempt to combine the above archaeological and geological approaches in order to evaluate the relative likelihood of the geographical areas mentioned above being a provenance for the chalk used to construct the Vine Street Town House mosaic floors.

\section{NORFOLK}

Although Chalk Group rocks form the bedrock of much of north and central Norfolk, their exposure is limited due to a much later deposition of Pleistocene sedimentary deposits. Chalks of Late Cenomanian and Early Turonian stages are exposed only as a long narrow ribbon running inland 
from the coast at Hunstanton along the chalk ridge (the East Anglian Heights) that separates the flat Fenland to the west from the flat Broads to the east. The chalk of these stages most easily accessed through the Roman road network is found around Swaffham and Thetford.

The western edge of the Heights culminates in the West Norfolk Ridge, an outcrop of sandstone and mudstone along which lies a small concentration of villas about $12-15 \mathrm{~km}$ to the north-west of Swaffham. Excavation of these villas revealed only plain mosaics appearing to date to the second century $A D$, suggesting these were early foundations; if they were still occupied in the fourth century, they do not seem to have installed any mosaics dating to this period ${ }^{41}$. Indeed, with the exception of the large cluster found in Colchester and its environs, Cosh and Neal record very few mosaics from East Anglia as a whole. This surprising absence of display of wealth in an area of generally rich farmland has been interpreted by Jones and Mattingly ${ }^{42}$ as evidence for the retarded development of the Icenian elite as a long-term legacy of the Boudican revolt and also possibly for the establishment of large imperial estates on confiscated land. The number of hoards of silver and gold coin and plate dating from the first to the fifth centuries found throughout Norfolk show that at least some local wealth did exist ${ }^{43}$; perhaps its owners preferred to keep it portable rather than to translate it into something more permanent. Certainly it does not appear to have been translated into mosaics: Cosh and Neal note that no fine mosaics of any period have yet come to light in the county and that plain red tessellated pavements are the norm, even in villas where excavation has revealed the presence of bath-houses and painted plaster ${ }^{44}$. It seems therefore that tessellation was regarded locally as more a functional than a decorative practice; and although this may, and probably did, involve the utilisation of local chalks, it does not suggest that these chalks were exploited on a large enough scale or for a long enough period to have acted as a source of tesserae for Leicester, some $120 \mathrm{~km}$ distant.

\section{THE CHILTERN ESCARPMENT}

Chalk dating to the Late Cenomanian and Early Turonian stages comprises, in this area of England, the upper part of the ZigZag Chalk Formation and the whole of the Holywell Nodular Chalk Formation ${ }^{45}$. Exposures of these two stages are found along the length of the northern edge of the Chiltern escarpment, from Cambridgeshire in the north east to Wiltshire in the south west, and although outcrops are nowhere large in scale and are occasionally very patchy, nevertheless the geographical area under consideration is extensive. 
Here again it is instructive to consider the Roman road network shown in Figure 5 . The routes south from Leicester ran in three directions: south-east to Colchester via Godmanchester; south-southeast along Watling Street towards St Albans and London; and south towards Silchester and the coast. These routes cross chalk of Late Cenomanian and Early Turonian age at Royston and Baldock, near to Stevenage in Hertfordshire; around Dunstable in Bedfordshire; and in the vicinity of Lambourn on the Berkshire Downs. It seems sensible therefore to look in these areas for evidence of the quarrying of chalk that could have been used to manufacture the Vine Street tesserae.

It is known that chalk from the Chiltern escarpment was utilised in Roman times. The second-century villa at Totternhoe in Bedfordshire utilised dressed blocks of Totternhoe Stone, the local 'clunch' (hard building stone), in the construction of foundations and hypocausts ${ }^{46}$ and a block of the same stone was found paving Watling Street under the Edgware Road in London ${ }^{47}$. Chalk blocks were also used in the construction of two early villas at Alfred's Castle ${ }^{48}$ and nearby Maddle Farm ${ }^{49}$, both sited on the Berkshire Downs close to Lambourn. There is also evidence of quarrying activities in the Chilterns. Chalk quarries or pits dating to the Roman period have been identified at Barrington, about $16 \mathrm{~km}$ south west of Cambridge ${ }^{50}$; at a site close to Todd's Green, about $3 \mathrm{~km}$ west of the A1(M) at Stevenage in Hertfordshire ${ }^{51}$; at Datchworth, also in Hertfordshire, a few kilometres south of Stevenage ${ }^{52}$; about $10 \mathrm{~km}$ south-west of Avebury in Wiltshire ${ }^{53}$; and possibly also at Verulamium (modern St Albans), both to the north ${ }^{54}$ and south ${ }^{55}$ of the Roman town.

All of the above quarrying sites are within reach of Leicester on the Roman road system, but none of them appears to have been the source of the chalk used for the Leicester tesserae. Totternhoe Stone, used at the eponymous villa and also excavated at Barrington, is mid-Cenomanian in age and so is slightly too early in date, and the quarries west and south of Stevenage and those at Verulamium expose chalks of a younger age, which are therefore too late. The series of shallow pits south-west of Avebury might expose chalk of the correct age, depending on their exact location, but the layout of the pits, dug parallel to the Roman road from Bath to Marlborough for $500 \mathrm{~m}$ on the north side of Morgan's Hill and about $1 \mathrm{~km}$ on the south side of Cherhill Down, suggests localised quarrying for hardcore for the metalling of the road rather than large-scale extraction. Other evidence for chalk quarrying in the Morgan's Hill and Cherhill Down area, which interestingly centres on linear extraction of the hard bed of Chalk Rock found locally, has been dated to the postmediaeval period ${ }^{56}$. 
There is, however, evidence that chalk of the correct age was quarried in the Roman period at Baldock in Hertfordshire. Baldock was an important settlement in the Late Iron Age that developed into a small town in the Roman period ${ }^{57}$. Excavation of a site in the north west of the town on a chalk ridge that probably formed the boundary of the Roman settlement was carried out by North Hertfordshire District Council's Field Archaeology Section ${ }^{58}$. The site (The Stationmaster's House) lies at the junction of the Icknield Way and the Roman road leading north from Baldock to Godmanchester and thence either to Lincoln or Leicester (Figure 5). Trial trenching exposed a large excavation in excess of $20 \mathrm{~m} \times 15 \mathrm{~m}$ in area and about $2.5 \mathrm{~m}$ in depth; this had been cut into the side of the chalk ridge and the chalk extracted using a series of smaller stepped cuts that had left angular faces. Contextual evidence suggests that the quarry came into use during the third century $A D$ and continued in use into the fourth. It is not possible to know what the extracted chalk was used for: chalk was used for agriculture as well as building and it is possible that even a large quarry may have served only Baldock and its environs. However, as the quarry lies directly on chalk of the Late Cenomanian and Early Turonian stages, and appears to have been operating at the time the Vine Street Town House was being refurbished, and also has good road access to Leicester, there is at least the possibility that it may have provided chalk for the Vine Street tesserae.

The Stationmaster's House quarry is not the only evidence for chalk extraction in Baldock. A large pit dug into the Holywell Nodular Chalk Formation discovered during excavation in advance of development in the town was also interpreted as a chalk quarry dating to the Roman period ${ }^{59}$. However, fill from this pit comprised a series of deposits of silty clay and redeposited chalk containing pottery dating from the second to the late third century AD. This would limit the quarrying activity to the first or early second centuries $A D$, which is too early a date to suggest that material from here might have been used in the production of the Vine Street tesserae. It will be interesting to see whether further excavation in the Baldock area uncovers additional evidence for chalk extraction and whether examination of chalk tesserae from elsewhere suggests that the material might have been supplied from the town.

The use of Totternhoe Stone raises the interesting question of chalk selection. It is noticeable that the Chalk Group rocks exposed at three of the above locations contained a condensed bed of hard, white chalk (Totternhoe Stone at both Totternhoe and Barrington, and Chalk Rock at Todd's Green west of the $A 1(M)$ at Stevenage). The question therefore arises as to whether these particular horizons were being sought out deliberately. This would make sense for the production of tesserae, as harder chalks should be considerably harder wearing underfoot than softer ones. In fact, the Late 
Cenomanian-Early Turonian Holywell Nodular Chalk Formation does include, both at Baldock and in the eastern reaches of the Chilterns, a condensed bed of hard, off-white, blocky fractured chalk (the Melbourn Rock Member) that would have been the 'right' age for a source for the Vine Street tesserae and might have been considered a suitable medium for their manufacture. But, disappointingly, no evidence has emerged from excavation to support the hypothesis that this hard bed of chalk was being specifically targeted for quarrying.

It is not possible to form a judgement as to whether Chiltern chalk travelled to Leicestershire. We know that Totternhoe Stone travelled from Bedfordshire to London. Tesserae cut from chalk are found at Little Wymondley villa in Hertfordshire, but as this villa is within a few kilometres of both Baldock and Stevenage, this does not constitute much of a movement of materials ${ }^{60}$. However, there is some evidence that material was travelling in the opposite direction. Swithland slate from Charnwood in north-west Leicestershire has been identified in roof tiles from one of the buildings at Bancroft in Buckinghamshire ${ }^{61}$ and also in dark blue-grey tesserae occurring in mosaics found at the villa ${ }^{62}$; and other possible identifications of Swithland slate have been made in fourth-century villa mosaics from nearby Foscott in Buckinghamshire and Thenford near Banbury in Northamptonshire ${ }^{63}$. McWhirr ${ }^{64}$ injects a cautious note concerning the identification of 'Swithland' slate, but nevertheless his records indicate that the material has been found at sites as far as $60-80 \mathrm{~km}$ from Ratae.

Assuming that the above identifications are correct, this evidence, although slight, does suggest a movement of Swithland slate southwards from Leicestershire during the mid-fourth century AD. This is perhaps not unconnected with the proposed Midlands Group of mosaicists active at the same time $^{65}$; as Neal and Cosh point out, mosaics at Bancroft Roman villa, located in the suburbs of Milton Keynes in Buckinghamshire and dating to around $350 \mathrm{AD}$, show strong stylistic similarities to coeval mosaics from villas at Drayton in Leicestershire ${ }^{66}$ and the slightly later mosaics at Great Casterton in Rutland ${ }^{67}$. Although any such movement of material (and possibly in the case of Bancroft, also mosaicists) is later than the suggested early-fourth century date for the Vine Street Town House mosaics, there is a possibility that it was a continuation of an earlier trend; in which case, it may not be implausible that chalk material from Baldock in Hertfordshire was moving northwards in a reciprocal movement. Indeed, the nearest source for the chalk tesserae found at the late third to early fourth century AD villa at Whitehall Farm on Watling Street, some $13 \mathrm{~km}$ north of Towcester, would be the Chiltern escarpment around Dunstable ${ }^{68}$. 


\section{THE NORTH EAST}

Late Cenomanian and Early Turonian stage chalk is also found in Lincolnshire and north-east Yorkshire, where it comprises the upper part of the Ferriby Chalk Formation and the lower part of the Welton Chalk Formation; the former consists mainly of grey, marly chalk whilst the latter is dominated by thick beds of chalk containing flint nodules ${ }^{69}$. Much of the solid geology in this area is obscured by Pleistocene sedimentary deposits, but the Chalk Group rocks to which these Formations belong are exposed along the steep slopes of the northern and western edges of the Yorkshire and Lincolnshire Wolds. The particular chalks of the Late Cenomanian and Early Turonian stage outcrop in a narrow band which curves inland from the Yorkshire coast at Bempton, close to Flamborough Head, before turning through ninety degrees to run south-east to the Humber estuary. From here the outcrop continues to run along the western scarp edge of the Lincolnshire Wolds to reach lower ground around Candlesby close to Skegness (Figure 5). As with the Chiltern escarpment, therefore, the Late Cenomanian-Early Turonian stage chalk outcrop in the Yorkshire and Lincolnshire Wolds is geologically constrained, but geographically extensive, and it is necessary to see if potential source areas can be identified through archaeological considerations.

About half of the thirty-odd Roman villa sites in Yorkshire are found on the western edge of the Yorkshire Wolds, where the chalk meets an impervious stratum to form a natural spring line and the soils are less heavy than those in the Vale of York and so easier for arable cultivation ${ }^{70}$. This is in contrast to Lincolnshire, where most of the villas are sited along or in proximity to Ermine Street and relatively few are sited on the Wolds themselves ${ }^{71}$. The majority of the mosaics found in these northeastern villas date to the third or fourth centuries $A D$ and are remarkable in that very few are figured: Neal and Cosh speculate that this might be a cultural rather than an economic phenomenon ${ }^{72}$. The rising prosperity of the north east in general and Yorkshire in particular during the third and fourth centuries $A D$ and possible reasons for the comparative lack of villas in the area are discussed succinctly in Wilson et al. ${ }^{73}$.

The main north-south movement of men and materials in the north east by-passed the chalk outcrops of Yorkshire and Lincolnshire. Traffic moved north along Ermine Street from Lincoln to the Humber crossing at Winteringham-Brough and north from there towards York, Catterick and the northern frontier. An alternative route north from Lincoln bypassed the Humber crossing by running inland to the Trent crossing at Littlethorpe and then on to York; this may even have become the preferred route north by the third century AD This meant that both the main routes north from Lincoln passed to the west of the chalk escarpment. However, Ermine Street was connected with 
potential chalk sources in the Wolds by a series of secondary routes. Two of these connected the main highway with ports on the east Lincolnshire and Yorkshire coasts: the more southerly of these ran from Lincoln to the coast at Skegness and a (presumed) ferry crossing across The Wash to a point west of Brancaster in north Norfolk, whilst the more northerly ran east from York across the Yorkshire Wolds to the coast at Bridlington. A third route ran north from the Humber estuary to the fort and settlement at Malton in the Vale of Pickering. Other roads, linking Ermine Street to its eastern hinterland (to Caistor, for instance), and linking Horncastle to Caistor and the Humber estuary at South Ferriby, have been suggested; practical considerations suggest that such routes must have existed, but definite evidence for them is lacking ${ }^{74}$.

Water transportation routes to Leicester from the east and north east were generally good. The town was connected to the Humber estuary via the rivers Soar and Trent, and to York by upstream travel on the Ouse. Lincoln, The Wash and the Fenlands were accessible through the Foss Dyke which connected the Trent at Torksey with the Witham to the west of Lincoln. However, only the Soar-Trent-Humber route passed close to any of the potential chalk source areas in the Wolds.

It is difficult to quantify the Roman use of chalk in the north east. The use of stone for building in York during the occupation has been well studied ${ }^{75}$ but there is little mention of chalk. Gaunt and Buckland ${ }^{76}$ state that chalk was used for sill walls on several Roman villa sites in East Yorkshire, but do not provide details of specific locations. Whitwell provides some information on quarrying activity around Lincoln and states that chalk was used for foundations for the putative Roman villa at Worlaby ${ }^{77}$. Other sources provide information on the use of chalk for tesserae. Gaunt and Buckland state that chalk was used extensively for the manufacture of white tesserae and that examples of such tesserae have been found in York, but without providing further details ${ }^{78}$ : Price and Wilson, however, state that chalk tesserae were found in pavements from Aldwark and Clementhorpe ${ }^{79}$. Neal and Cosh record about ten mosaics from York; they also record over thirty mosaics from the colonia at Lincoln and a further ten from the nearby villa at Greetwell, but unfortunately without being able to confirm the use of chalk tesserae in any of them ${ }^{80}$. However, they do record the presence of chalk tesserae in pavements from Haceby in Lincolnshire and from Aldborough, Harpham, Langton and Wharram Grange in Yorkshire, all of early, or probable, fourth century AD date $^{81}$. Chalk tesserae were also used in pavements at the Roman villa at Winterton (sited about 10 $\mathrm{km}$ north of Scunthorpe) and chalk tesserae chippings were found above a floor in one of its rooms (Room 21), the suggestion being that the latter were the residue from patching work undertaken on some of the mosaics at the other end of the building ${ }^{82}$. Pragmatism suggests that some of the 'white 
tesserae' described by Neal and Cosh as making up the background, borders or fine detail of the (largely) geometric patterned pavements found elsewhere in Yorkshire and Lincolnshire were also manufactured from local chalks, but in the absence of positive identification, this has to remain a conjecture.

With regard to provenance, the chalk tesserae found at Winterton in north Lincolnshire are described as local ${ }^{83}$ and indeed the villa is less than $10 \mathrm{~km}$ from the foot of the chalk escarpment of the Lincolnshire Wolds. However, Neal and Cosh report that the white tesserae found in Hull and East Riding Museum and attributed to the fourth-century villa at Harpham were found by the museum to have originated from sea-worn rock chalk pebbles and may have come from the chalk shore source closest to the villa, which is the bay at Bridlington about $10 \mathrm{~km}$ to the east ${ }^{84}$. This is interesting, as the excavation report for the much earlier baths at Well in Yorkshire, sited north of Ripon and about $5 \mathrm{~km}$ west of Ermine Street on its inland route between Isurium Brigantum and Cataractonium, gives a probable geological provenance of 'the beach area north of Bridlington' for tesserae found at the site that are made from a hard white chalk ${ }^{85}$. As Bridlington is over $100 \mathrm{~km}$ from Well, assuming travel westwards from the coast across the Wolds to York and then northwards via Ermine Street, this would imply that chalk from the coast was travelling a considerable distance inland by about the mid-second century AD.

It is possible that Bridlington might have been a source of chalk for tesserae. The regional dip of the Chalk Group rocks to the north and south of Flamborough Head exposes a succession of stages around the coastal cliffs, which includes an exposure of Late Cenomanian and Early Turonian stage chalk to the north of Bridlington around Bempton Cliffs. Sections of these coastal chalk exposures are today difficult or even impossible to access ${ }^{86}$, but the coastline may have been considerably different in Roman times. If the above provenances are correct, therefore, these coastal exposures might have provided chalk for tesserae found at Harpham and at Well, and also for other villas in the region. In this context, it is perhaps worth noting the piles of tesserae found during excavation at the nearby villa at Rudston. The tesserae found in Building 3 at Rudston were sorted by size and colour, whilst those found in Building 7 were unsorted but numbered around $1500^{87}$. This was thought by Smith to constitute evidence for the manufacture of tesserae at the villa, either for domestic use or as a cottage industry ${ }^{88}$. It is interesting to note that, of the material found in Building 3 , the largest pile was of small white tesserae. If these were cut from chalk, it is possible that they too may have been sourced from the Bridlington area. 
Given the above information, it would not be surprising to find that chalk for the local production of tesserae was quarried either from exposures on the shore or inland in the Wolds, even though evidence for quarrying on the scale of the excavations described above at Baldock has not been found. However, it is hard to prove that any such material might have moved to Leicester. Neal and Cosh identify stylistic affinities with two mosaics in Leicester in a second-century mosaic from Well, suggesting that it might be the product of the same craftsmen, and also in a fourth-century mosaic from Haceby ${ }^{89}$, and the use of Leicestershire Swithland slate roof tiles at the settlement of Haceby is attested $^{90}$, but this does not constitute enough information to demonstrate a strong link between the two areas. However, accessible chalk of the same age as that used to manufacture the Vine Street tesserae is found in the north east, including around Bridlington; many of the mosaics laid in the north east date to the fourth century and so were utilising chalk tesserae at the same time as the Vine Street mosaics are thought to have been laid; and the piles of tesserae at Rudston might possibly be evidence of a tesserae workshop, if only a local one. This means that a source of chalk in the north east for the Vine Street tesserae is still a tantalising possibility.

\section{THE SOUTH}

Much of the Chalk Group responsible for the familiar chalk landscapes of southern England is younger than the chalk used to manufacture the Vine Street tesserae. Outcrops of Late Cenomanian and Early Turonian stage chalk are limited to the scarp faces of the North and South Downs, a narrow outcrop in the Isle of Wight ${ }^{91}$ and an Early Turonian outcrop at beach level at Beer in south Devon. The exposures on the Downs tend to be elongate and are occasionally intermittent, but in general terms form a horseshoe whose arms run north-east and south-east from the vicinity of Petersfield in Hampshire. Broadly speaking, the northern arm of the horseshoe follows the line of the North Downs Way to culminate in cliffs at Folkestone and Dover and the southern arm of the horseshoe follows the line of the South Downs Way to culminate in cliffs at Beachy Head. The relevant chalk outcrops are crossed by a series of Roman roads originating from London and connecting the port with the south and east coasts (Figure 5). All of these routes provided good communications with Leicester.

Both south-east and south-central England were occupied and settled earlier than the rest of Britannia and experienced earlier prosperity. However, the continual uneasiness and sporadic instability of the political situation at home and on the continental mainland during the third century may have effected a downturn in the economic prosperity of the region during the fourth, particularly in the south east. This would explain the large number of mosaics in this region that can 
be dated to the second century and the comparatively few that can be dated to the fourth ${ }^{92}$. This economic situation is very different to the one found in the south west and also in the north east: in these areas, villas were being established or developed during much of the fourth century and a considerable number of mosaics and several mosaic workshops date to this period ${ }^{93}$.

Chalk tesserae are confirmed at several sites in the south, although the widespread use by mosaicists of the paler geological facies in both geometric and figured pavements suggests that it must have been used at very many more. Neal and Cosh record the use of chalk tesserae from mosaics found in Hampshire, at West Meon ${ }^{94}$; in West Sussex, at Chilgrove, Fishbourne, Pulborough and Southwick and in East Sussex at Preston ${ }^{95}$; in Kent, at Boxted and Folkestone ${ }^{96}$; and in Surrey, at Walton-on-the-Hill and Worpleston ${ }^{97}$. Chalk tesserae have also been identified from town houses in Ilchester in Somerset, at sites in Church Street ${ }^{98}$ and in Castle Yard, High Street and Limington Road $^{99}$; in Dorset at Halstock villa, near to $\|_{\text {llchester }}{ }^{100}$ and at the Applegates site in Dorchester ${ }^{101}$; and in Wiltshire, at Badbury and Tockenham ${ }^{102}$. Of the mosaics that are dated, only those from sites further west (Ilchester, West Meon, Chilgrove, Badbury and Halstock) are fourth century; the other sites either flourished earlier or are of unknown date. It is likely that this reflects the greater stability and affluence of the west of the province at this time, as evinced by the groups of mosaicists thought to have been operating out of Dorchester and the Cirencester area in the fourth century ${ }^{103}$.

In five instances the provenance of the chalk used to manufacture tesserae in the south is either known, or strongly suspected. The chalk tesserae workshop at Norden, Corfe Castle, in the Isle of Purbeck $^{104}$ seems to have utilised chalk from a local source ${ }^{105}$, as apparently did mosaicists at Brading Roman villa on the Isle of Wight ${ }^{106}$; chalk from Dorset was used to manufacture tesserae for mosaics from Silchester ${ }^{107}$; chalk from Stonehill Down, Purbeck, was used for tesserae from the Applegates site in Dorchester ${ }^{108}$; and chalk from the Marlborough Downs was identified from Tockenham ${ }^{109}$. Tesserae at Norden were being produced as early as $70 \mathrm{AD}$, but the evidence suggests that activity at the site declined after the mid second century before experiencing a modest revival in the late third. Whether this revival included the manufacture of chalk tesserae is not clear, but there is not much evidence for it; very few tesserae have been found dating to this period (only 16 , as opposed to the $>1500$ examples and their associated waste chippings from the earlier context) and the later chalk material consisted predominantly of sawn slabs of chalk for use as floor tiles or wall veneers ${ }^{110}$. It would appear therefore that chalk tesserae manufacture at Norden was confined almost entirely to the earlier period, and as Sunter points out, it might not be a coincidence that this coincided with the construction of floors for the Flavian villa at Fishbourne. 
The possibility of supplying chalk to Leicester from the south of the province is an interesting one, given its technical feasibility and the fact that other lithologies are known to have travelled considerable distances. However, the archaeological evidence for any actual quarrying of chalk in the south in Roman times is limited, which makes it difficult to suggest a possible source area. Chalk quarries dating to the Roman period have been identified during excavation at the County Hospital $^{111}$ and Colliton Park ${ }^{112}$ sites in Dorchester in Dorset and possibly also to the west of the town at Middle Farm ${ }^{113}$ and Winterbourne Monkton ${ }^{114}$; at Tilshead in Wiltshire ${ }^{115}$; in Kent, at Birchington in Thanet ${ }^{116}$ and at Chartham near Canterbury ${ }^{117}$; and also at Coulsden in Croyden ${ }^{118}$ and close to the London Road at Purfleet in Essex ${ }^{119}$. However, the main periods of operation for all of these quarrying activities appears to have been before the mid-third century $A D$, so if they were supplying chalk to a wider hinterland than their immediate neighbourhood, it does not seem that any of them was still in production at the time of the laying of the Vine Street mosaic. Also, none of the quarries discovered appears to have been sited on the rather limited outcrops of Late Cenomanian or Early Turonian chalk and so none could have acted as a source for the Vine Street tesserae.

This lack of evidence for chalk quarrying in the south of England after the mid-third century, coupled with the paucity of later mosaics from the south east, does not suggest a thriving mosaic industry in this part of the province. It is worth noting that a number of mid-fourth century mosaics from Silchester and London show stylistic affinities with the Saltire Group of mosaicists working out of Cirencester (Corinium): in the case of London, Neal and Cosh speculate that this might be because the London-based Acanthus workshop may have ceased to operate by the late third or early fourth century $A D$ and so expertise had to be imported from the west ${ }^{120}$. Probably, this makes it unlikely that the chalk for the Vine Street tesserae was sourced from anywhere in the south east, although it does not eliminate possible sources further south and west. This begs the question of where the chalk for the many fourth century mosaics being laid by the Corinium and Durnovarian Groups in the west and south west was being sourced, and also whether the mosaic 'workshops' operating out of the region at this time were using the same or different sources of chalk. A microfossil analysis of chalk tesserae from a selection of these mosaics, similar to that carried out on the Vine Street tesserae for this paper, might provide some answers and the authors commend this approach to future researchers. 
It is clear from the above discussion that it is not possible to draw a definite conclusion as to the provenance of the chalk tesserae used in the construction of mosaics in the Vine Street Town House. However, it has been possible to suggest two possible source locations, both of which satisfy the geological and the archaeological criteria. These are Baldock in Hertfordshire and Bridlington in Yorkshire. Baldock is the nearer of the two and the easier of access, given the road network, and therefore on these grounds, the more convincing suggestion. However, we should not discount the possibility of a northern source. The slower rise to prosperity in the north east meant that mosaics were being laid there well into the fourth century $A D$, which must have created a demand for materials, if only a local one. Further investigation into the provenance of chalk tesserae from mosaics in Yorkshire might yet produce surprises.

\section{ACKNOWLEDGEMENTS}

The authors would like to thank the University of Leicester Archaeological Services (ULAS) for providing chalk tesserae from the Vine Street Town House for analysis. IPW publishes with the permission of the Executive Director of the British Geological Survey (N.E.R.C.).

Alison Tasker (corresponding author). Department of Geology, University of Leicester, University Road, Leicester LE1 7RH, UK. aht7@le.ac.uk

I.P. Wilkinson. British Geological Survey, Keyworth, Nottingham NG12 5GG, UK.

M. Williams. Department of Geology, University of Leicester, University Road, Leicester LE1 7RH, UK.

M. Morris, N. Cooper. University of Leicester Archaeological Services (ULAS), University of Leicester, University Road, Leicester LE1 7RH, UK.

M.G.Fulford, School of Human and Environmental Sciences, University of Reading, Reading RG6 6AB, UK. 
${ }^{1}$ Cosh and Neal 2006, 2010; Neal and Cosh 2002, 2009

${ }^{2}$ For example, Rainey, 1973; Johnson, 1987; and more recently, Ling 1997; Witts 2005

${ }^{3}$ Smith 1969; Johnson 1987

${ }^{4}$ Wilkinson et al. 2008

${ }^{5}$ Tasker et al. 2011

${ }^{6}$ For example, by Neal and Cosh 2002, 69.

${ }^{7}$ Flügel and Flügel 1997; Flügel 1999, 2004

${ }^{8}$ Allen and Fulford 2004; Allen et al. 2007

${ }^{9}$ Hayward 2009

${ }^{10}$ Wilkinson et al. 2008; Tasker et al. 2011

${ }^{11}$ Flügel 1999

${ }^{12}$ Flügel and Flügel, 1997

${ }^{13}$ Allen and Fulford 2004

${ }^{14}$ Allen et al. 2007

${ }^{15}$ Hayward 2009

${ }^{16}$ Winchester 2001

${ }^{17}$ Armstrong and Brasier 2005

${ }^{18}$ Quinn 2008

${ }^{19}$ Liddle 1982

${ }^{20}$ Score 2006; Hargrave 2009

${ }^{21}$ Clay and Pollard, 1994, 46

${ }^{22}$ Mattingly 2007, 140-1

${ }^{23}$ Cooper 2006, 147; Higgins et al. 2009, 3

${ }^{24}$ Johnson 1980

${ }^{25}$ Connor and Buckley 1999

${ }^{26}$ Higgins et al. 2009

27 Johnson 1980; Neal and Cosh 2002; Higgins et al. 2009

${ }^{28}$ Neal and Cosh 2002, 110-115

${ }^{29}$ Neal and Cosh 2002, 123, 127

${ }^{30}$ Archaeological context numbers for the locations of the redeposited tesserae and the Small Find 1084 are given in Tables 2-5. These can be related to the relevant context descriptions in Higgins et al. 2009. 
${ }^{31}$ Slipper 1997

${ }^{32}$ Hart et al. 1989 and references therein

${ }^{33}$ Wilkinson 2000, 2011a

${ }^{34}$ See Wilkinson $2011 \mathrm{~b}$ for a fuller analysis of the stratigraphic value of Pithonella sphaerica.

${ }^{35}$ Tasker et al. 2011

${ }^{36}$ Wilkinson et al. 2008

${ }^{37}$ Wilkinson and Riding 2008

${ }^{38}$ Hayward 2009

${ }^{39}$ Hayward 2009, 52, 147; 67, 103

${ }^{40}$ Hayward 2009, 98-9

${ }^{41}$ Cosh and Neal 2006, 211-219

42 Jones and Mattingly 1990

${ }^{43}$ Abdy 2002, 67-9. Norfolk hoards have been found dating to the first century AD (Eriswell, Howe), the second and third centuries (Snettisham, Mattishall) and late Roman times (Hockwald). Two other hoards, the North Suffolk Forger's Hoard (first century AD) and the Hoxne Treasure (late Roman) were found in Suffolk.

${ }^{44}$ Cosh and Neal 2006, 213

${ }^{45}$ Hopson 2005

${ }^{46}$ Matthews et al. 1992

${ }^{47}$ Coddrington 1903

${ }^{48}$ Gosden \& Lock 2003, 73

${ }^{49}$ NMR1029200

${ }^{50}$ Collins and Knight 2007

${ }^{51}$ Hertfordshire HER 11534

${ }^{52}$ Hertfordshire HER 1898

${ }^{53}$ Small 1999, 21-2

${ }^{54}$ Hertfordshire HER 14329

${ }^{55}$ Hertfordshire HER 6205

${ }^{56}$ Small 1999

${ }^{57}$ Brown 1995

${ }^{58}$ Atkinson et al. 1992

${ }^{59}$ Fenton et al. 2003 
${ }^{60}$ Burleigh et al. 1990

${ }^{61}$ Neal and Cosh 2002, 24

${ }^{62}$ Neal, 1981, 43; Williams and Zeepvat 1994, 259 'probably'; Neal and Cosh 2009, 51

${ }^{63}$ Neal and Cosh 2009, 56

${ }^{64} \mathrm{McWhirr} 1988$

${ }^{65}$ Neal 1981, 43; Neal and Cosh 2002, 24

${ }^{66} \mathrm{Neal}$ and Cosh 2002, 24

${ }^{67}$ Neal and Cosh 2009, 49

${ }^{68}$ Young 2006

${ }^{69}$ Hopson 2005

${ }^{70}$ Halkon 2010

${ }^{71}$ For an overview, see Neal \& Cosh 2002, 132-4

${ }^{72}$ Neal and Cosh 2002, 134

${ }^{73}$ Wilson et al. 1984

${ }^{74}$ For a discussion of the evidence for the above routes, see Whitwell 1992

${ }^{75}$ Buckland 1988; Gaunt and Buckland 2002; Pearson 2006

${ }^{76}$ Gaunt and Buckland 2002, 141

${ }^{77}$ Whitwell 1992, 39, 116

${ }^{78}$ Gaunt and Buckland 2002, 141

${ }^{79}$ Price and Wilson 1988, 266 (citing Smith in Brinklow et al. 1986)

${ }^{80}$ Neal and Cosh 2002, 368-378 (York); 163-183 (Lincoln and Greetwell)

${ }^{81}$ Neal \& Cosh 2002, 144, 318, 339, 342 and 367 respectively

${ }^{82}$ Stead 1976, 272, 46-7

${ }^{83}$ Stead 1976, 272

${ }^{84} \mathrm{Neal}$ and Cosh 2002, 339; also Sheppard 1940

85 Versey, in Gilyard-Beer 1951, 68. The citation in Gilyard-Beer for Versey's original article is incorrect and unfortunately I have been unable to trace the article. H.C. Versey was Emeritus Professor of Geology at Leeds University.

${ }^{86}$ Mortimore et al. 2001, 410

${ }^{87}$ Stead 1980, 13, 17-18

${ }^{88}$ Smith, in Stead 1980, 131-138 'Mosaics'

${ }^{89}$ Neal and Cosh 2002, 364, 366 (Well); 144 (Haceby) 
${ }^{90}$ McWhirr 1988

${ }^{91}$ Hopson 2011

${ }^{92}$ Neal and Cosh 2009, 3, 19

${ }^{93}$ Cosh and Neal 2006, 5, 21-30 and references therein

${ }^{94}$ Neal and Cosh 2009, 250

${ }^{95} \mathrm{Neal}$ and Cosh 2009, 520, 532, 555 and 557 respectively (West Sussex); 555 (East Sussex)

${ }^{96}$ Neal and Cosh 2009, 359, 377

${ }^{97}$ Neal and Cosh 2009, 477, 478

${ }^{98}$ Somerset HER 55896

${ }^{99}$ Cosh \& Neal 2006, 216, 220 and 225 respectively

${ }^{100}$ Cosh \& Neal 2006, 142

101 Jones 1989

${ }^{102}$ Cosh \& Neal 2006: 318, 365 respectively

${ }^{103}$ Cosh and Neal 2006, 21-30

${ }^{104}$ Sunter and Woodward 1987

${ }^{105}$ Wilkinson et al. 2008

${ }^{106}$ Tasker et al. 2011

${ }^{107}$ Wilkinson et al. 2008

108 Jones 1989

${ }^{109}$ Cosh \& Neal 2006, 365 (citing Harding and Lewis 1997)

${ }^{110}$ Sunter and Woodward 1987, 36

${ }^{111}$ Dorset HER MDO 18960

${ }^{112}$ Dorset HER MDO 1041758

${ }^{113}$ Dorset HER 1041534

${ }^{114}$ Dorset HER 1130153

${ }^{115}$ Wiltshire SMR SU 14 NW 306

${ }^{116}$ Kent HER 467373

${ }^{117}$ Burnham et al. 1997, 452

${ }^{118}$ HER 403828

${ }^{119}$ White 2008, 2

${ }^{120}$ Neal \& Cosh 2009, 191, 400-1, 437 


\section{BIBLIOGRAPHY}

Abdy, R.A. 2002: Romano-British Coin Hoards. Shire Archaeology, Princes Risborough.

Allen, J. and Fulford, M. 2004: 'Early Roman mosaic materials in southern Britain, with particular reference to Silchester (Calleva Atrebatum): a regional geological perspective', Britannia 35, 9-38.

Allen, J.R.L., Fulford, M.G. and Todd, J.A. 2007: 'Burnt Kimmeridgian shale at Early Roman Silchester, south-east England, and the Roman Poole-Purbeck complex-agglomerated Geomaterials Industry', Oxford Journal of Archaeology 26, 167-191.

Armstrong, H. and Brasier, M. 2005: Microfossils, Wiley-Blackwell.

Atkinson, M., Burleigh, G. and Went, D. 1992: An Archaeological Investigation of the Stationmaster's House: 16 Station Road, Baldock, Hertfordshire, Field Archaeology Report Series, North Hertfordshire District Council.

Buckland, P. 1988: 'The stones of York: building materials from Roman Yorkshire', in Price, J. and Wilson, P.R. (eds), Recent Research in Roman Yorkshire, studies in honour of Mary Kitson Clark (Mrs Derwas Chitty), 237-287, British Archaeological Report British Series 193, Oxford.

Burleigh, G. 1995: 'The plan of Romano-British Baldock, Hertfordshire', in Brown, A. (ed.), Roman Small Towns in Eastern England and Beyond, 177-182, Oxbow Books, Oxford.

Burleigh, G., Went, D. and Colley, C. 1990: An archaeological evaluation of a Romano-British site on the route of the Little Wymondley Bypass, Hertfordshire, English Heritage.

Burnham, B.C., Keppie, L.J.F., Cleary, A.S.E. and Tomlin, R.S.O. 1997: 'Roman Britain in 1996', Britannia 28, 395-472.

Clay, P. 2001: 'Leicestershire and Rutland in the First Millennium BC', Transactions of the Leicestershire Archaeological and Historical Society, 75.

Clay, P. and Pollard, R. 1994: Iron Age and Roman Occupation in the West Bridge Area, Leicester. Excavations 1962-1971. Leicestershire Museums Arts and Records Service, Leicester.

Coddrington, T. 1903: Roman Roads in Britain, Society for Promoting Christian Knowledge, London.

Collins, M. and Knight, M. 2007: Barrington Cement Quarry: Excavation at the edge of a Roman Settlement at Wilsmere Down Farm, Cambridgeshire, Cambridge Archaeological Unit, Cambridge. 
Connor, A. and Buckley, R. 1999: Roman and Medieval Occupation in Causeway Lane, Leicester, Leicester Archaeology Monographs 13, University of Leicester Archaeological Services, Leicester.

Cooper, N. (ed) 2006: The Archaeology of the East Midlands. An Archaeological Resource Assessment and Research Agenda, Leicester Archaeology Monographs 13, University of Leicester Archaeological Services, Leicester.

Cosh, S.R. and Neal, D.S. 2006: Roman Mosaics of Britain. Volume II: South-West Britain, Illuminata Publishers, London.

Cosh, S.R. and Neal, D.S. 2010: Roman Mosaics of Britain, Volume IV: West Britain, Society of Antiquaries, London.

Fenton, P., Winter, M. and Ashworth, H. 2003: The Former Health Centre, The Tene, Baldock, Herts, The Heritage Network Ltd.

Flügel, E. and Flügel, C. 1997: 'Applied microfacies analysis: Provenance studies of Roman mosaic stones', Facies 37, 1-48.

Flügel, E. 1999: 'Microfacies-based provenance analysis of Roman imperial mosaic and sculpture materials from Bavaria (Southern Germany)', Facies 41, 197-208.

Flügel, E. 2004: Microfacies of carbonate rocks: analysis, interpretation and application. SpringerVerlag, Stuttgart.

Gaunt, G. and Buckland, P. 2002: 'Sources of Building Material in Roman York', in Wilson, P.R. and Price, J. (eds), Aspects of Industry in Roman Yorkshire and the North, 133-144, Oxbow Books, Oxford.

Gilyard-Beer, R. 1951: The Romano-British Baths at Well, Yorkshire Archaeological Society, Roman Antiquities Committee, Leeds.

Gosden, C. and Lock, G. 2003: 'Becoming Roman on the Berkshire Downs: The Evidence from Alfred's Castle', Britannia 34, 65-80.

Halkon, P. 2010: 'Britons and Romans in an East Yorkshire Landscape, UK', Bollettino di Archeologia on line, volume speciale $E$ / E10 / 3 .

Harding, P. and Lewis, C., 'An Archaeological Investigation at Tockenham, 1994', Wiltshire Archaeology and Natural History Magazine 90, 26-41. 
Hargrave, F. 2009: 'The Hallaton Treasure: evidence of a new kind of shrine?', Current Archaeology 20 (236).

Hart, M., Bailey, H., Crittendon, S., Fletcher, B., Price, R. and Swiecicki, A. 1989: 'Cretaceous', in Jenkins, D., Murray, J. (eds.), Stratigraphical Atlas of Fossil Foraminifera, 273-371, Ellis Horwood Limited, Chichester.

Hayward, K.M. 2009: Roman Quarrying and Stone Supply on the Periphery - Southern England. A geological study of first century funeral monuments and monumental architecture, British Archaeological Report British Series 500, Archaeopress, Oxford.

Higgins, T., Morris, M. and Stone, D. 2009: Life and Death in Leicester's North-east Quarter: Excavation of a Roman Town House and Mediaeval Parish Churchyard at Vine Street, Leicester (Highcross Leicester) 2004-2006, University of Leicester Archaeological Services, Leicester.

Hopson, P. 2005: A stratigraphical framework for the Upper Cretaceous Chalk of England and Scotland with statements on the Chalk of Northern Ireland and the UK offshore sector, British Geological Survey, Keyworth.

Hopson, P. 2011: 'The geological history of the Isle of Wight: an overview of the 'diamond in Britain's geological crown"', Proceedings of the Geologists' Association 122, 745-763.

Johnson, P. 1980: 'The Mosaics of Roman Leicester', Transactions of the Leicestershire Archaeological and Historical Society 55.

Johnson, P. 1987: Romano-British mosaics, Osprey Publishing, Oxford.

Jones, B. and Mattingly, D. 1990: An Atlas of Roman Britain, Blackwell Publishers, Oxford.

Jones, M.E. 1989: 'White tesserae from Roman Dorchester', Proceedings of the Dorset Natural History and Archaeological Society 110, 160-161.

Liddle, P. 1982: Leicestershire Archaeology: the present state of knowledge. Vol 1: To the end of the Roman period, Leicestershire Museums, Art Galleries and Records Service, Leicester.

Ling, R., 1997. 'Mosaics in Roman Britain: Discoveries and Research since 1945', Britannia, 28, 259295.

Matthews, C., Schneider, J. and Horne, B. 1992: 'A Roman Villa at Totternhoe', Bedfordshire Archaeology 20.

Mattingly, D. 2007: An imperial possession: Britain in the Roman Empire, 54 BC-AD 409, Penguin. 
McWhirr, A. 1988: 'The Roman Swithland Slate Industry', Transactions of the Leicestershire Archaeology and Historical Society 62.

Mortimore, R.N., Wood, C.J. and Gallois, R.W. 2001: British Upper Cretaceous Stratigraphy, Geological Conservation Review 23, Joint Nature Conservation Committee, Peterborough.

Neal, D.S. 1981: Roman mosaics in Britain: an introduction to their schemes and a catalogue of paintings, Society for the Promotion of Roman Studies, London.

Neal, D.S. and Cosh, S.R. 2002: Roman Mosaics of Britain. Volume I: Northern Britain, Illuminata Press with the Society of Antiquaries of London, London.

Neal, D.S. and Cosh, S.R. 2009: Roman Mosaics of Britain. Volume III: South-East Britain, Society of Antiquaries of London, London.

Pearson, A.F. 2006: The work of giants: stone and quarrying in Roman Britain, Tempus, Stroud.

Price, J. and Wilson, P.R. (eds), 1988: Recent research in Roman Yorkshire : studies in honour of Mary Kitson Clark (Mrs Derwas Chitty), British Archaeological Report British Series 193, Oxford.

Quinn, P. 2008: 'The occurrence and research potential of microfossils in inorganic archaeological materials', Geoarchaeology 23, 275-291.

Rainey, A. 1973: Mosaics in Roman Britain: a gazetteer, David and Charles, Newton Abbott.

Score, V. 2006: 'Rituals, hoards and helmets: a ceremonial meeting place of the Corieltavi', Transactions of the Leicestershire Archaeological and Historical Society 80, 197-207.

Sheppard, T. 1940: 'Origin of some Roman roofing tiles', The Naturalist, 152.

Slipper, I.J. 1997: 'Turonian (Late Cretaceous) Ostracoda from Dover, South-east England', unpublished PhD thesis, University of Greenwich.

Small, F. 1999: The Avebury World Heritage Site Mapping Project, Wiltshire, Royal Commission on Historical Monuments of England.

Smith, A. 1969: 'The Mosaic Pavements', in Rivet, A. L. F. (ed.), The Roman Villa in Britain, London, London.

Smith, D. 1980: 'Mosaics', in Stead I.M., Rudston Roman Villa, 131-138, Yorkshire Archaeological Society, Leeds, Yorkshire.

Stead, I.M. 1980: Rudston Roman Villa, Yorkshire Archaeological Society. 
Sunter, N. and Woodward, P. 1987: Romano-British Industries in Purbeck. Excavation at Norden, Ower and Rope Lake Hole. All three sites in the parish of Corfe Castle, Dorset, Dorset Natural History and Archaeological Society, Dorchester, Dorset.

Tasker, A., Wilkinson, I.P., Fulford, M.G. and Williams, M. 2011: 'Provenance of chalk tesserae from Brading Roman Villa, Isle of Wight, UK', Proceedings of the Geologists' Association 122, 933937.

White, G. 2008: Purfleet Riverside, London Road, Purfleet, Essex. Archaeological Watching Brief Report, Wessex Archaeology, London.

Whitwell, J.B. 1992: Roman Lincolnshire (Revised edition), History of Lincolnshire Vol. 2, The History of Lincolnshire Committee, Lincoln.

Wilkinson, I.P. 2000: A preliminary foraminiferal biozonation of the Chalk Group (in preparation for the Holostrat Project: Upper Cretaceous), NERC Open Research Archive (N.O.R.A.), British Geological Survey, Keyworth.

Wilkinson, I.P. 2011a: 'Foraminiferal biozones and their relationship to the lithostratigraphy of the Chalk Group of southern England', Proceedings of the Geologists' Association 122, 842-849.

Wilkinson, I.P. 2011b: 'Pithonellid blooms in the Chalk of the Isle of Wight and their biostratigraphical potential', Proceedings of the Geologists' Association 122, 862-867.

Wilkinson, I.P., Williams, M., Young, J.R., Cook, S.R., Fulford, M.G. and Lott, G.K. 2008: 'The application of microfossils in assessing the provenance of chalk used in the manufacture of Roman mosaics at Silchester', Journal of Archaeological Science 35, 2415-2422.

Wilkinson, I. and Riding, J. 2008: Provenance of the Oadby Till at Buddon Wood Quarry, Mountsorrel, Leicestershire, British Geological Survey Report, British Geological Survey, Keyworth. Accessd at: http://nora.nerc.ac.uk/6770/ on 22 June 2011.

Williams, R. and Zeepvat, R. 1994: A Late Bronze Age/Iron Age Settlement, Roman Villa and TempleMausoleum. Volume 1: Excavation and Building Materials, Monograph 7, Buckinghamshire Archaeological Society, Aylesbury, Buckinghamshire.

Wilson, P.R., Jones, R.F.M. and Evans, D.M. 1984: Settlement and Society in the Roman North, School of Archaeological Sciences, University of Bradford and Roman Antiquities Section, Yorkshire Archaeological Society, Leeds, Yorkshire.

Winchester, S. 2001: The Map That Changed the World: William Smith and the Birth of Modern Geology, HarperCollins, London. 
Witts, P. 2005: Mosaics in Roman Britain: stories in stone, Tempus, Stroud.

Young, S. 2006: 'Whitehall Farm Roman Villa \& Landscape Project. Fieldwork. Summer Excavation 2006'. Accessed at: http://www.whitehallvilla.co.uk/htmlfiles/dig2006.html. 


\section{FIGURE CAPTIONS}

Figure 1a. Plan of Roman Leicester (Ratae Corieltavorum) showing the location of the Vine Street Town House in Insula V (inset: UK location map for Leicester). Plan courtesy of ULAS.

Figure 1b. Plan of the Vine Street Town House, Leicester, in the third to mid-fourth centuries AD, showing the location of Room 6. Plan courtesy of ULAS.

Figure 2: Thin section images of microfossils found in chalk tesserae from Vine Street Town House, Leicester, UK. 2.1: Dicarinella hagni (MPK 14370: ex MPA 62491); 2.2: Pithonella sphaerica in flood proportions (MPK 14371: ex MPA 62494); 2.3: Marginotruncana marginata (MPK 14373: ex MPA 62491); 2.4: Dicarinella canaliculata (MPK 14372: ex MPA 62492). Note that the majority of specimens in image 2.2 are Pithonella sphaerica, but that $P$. ovalis also occurs in small numbers.

Figure 3: Upper Cretaceous (Cenomanian and Turonian) lithostratigraphy and biostratigraphy for chalks of northern $(\mathrm{N})$ and southern $(\mathrm{S})$ England. The frequency and abundance of pithonellid blooms for chalks of southern England are shown. The faunal biozones follow those of Wilkinson (2000). The shaded area represents the stratigraphic age range for the chalk tesserae from Vine Street.

Figure 4: Till of the Oadby Member (Quaternary) at outcrop, showing entrained chalk fragments. Picture courtesy of Dr Keith Ambrose, British Geological Survey.

Figure 5. Sketch map of England and Wales, showing (i) the distribution of Upper Cretaceous Chalk Group rocks and their intersection with Roman roads and (ii) main towns mentioned in the text (modern names). Cretaceous Chalk data taken from Geological Conservation Review volume 12 (1997) Karst and Caves of Great Britain, Chapter 7 and Figure 1. Sketch map of Cenomanian and Turonian age chalk taken from BGS Edina Digimaps (Geological Map Data (C) NERC 2011). Roman roads based on Ordnance Survey map of Roman Britain (5th edition) (2001). 


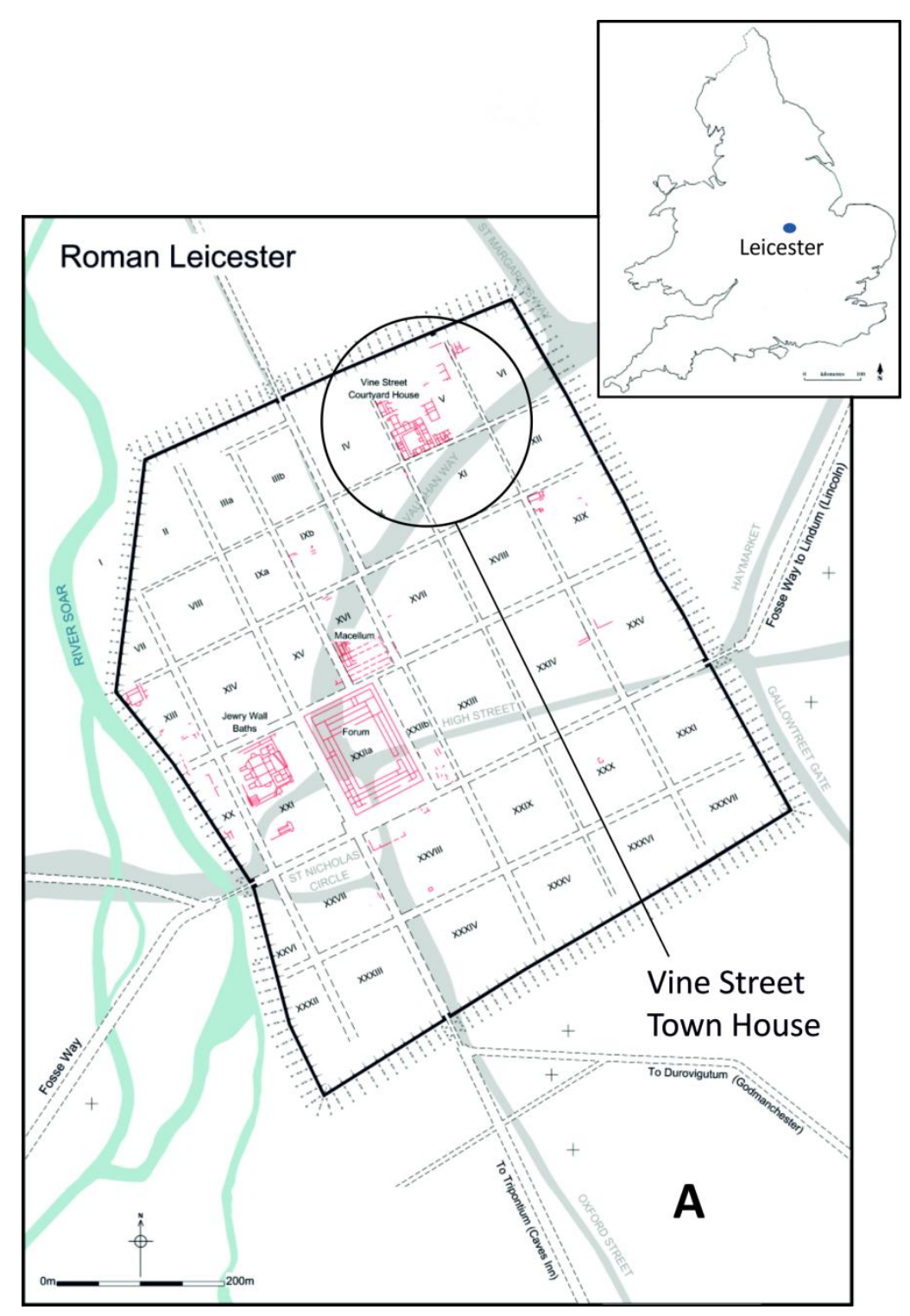


$\underline{\text { Tasker et al./Figure } 1 \mathrm{~b}}$

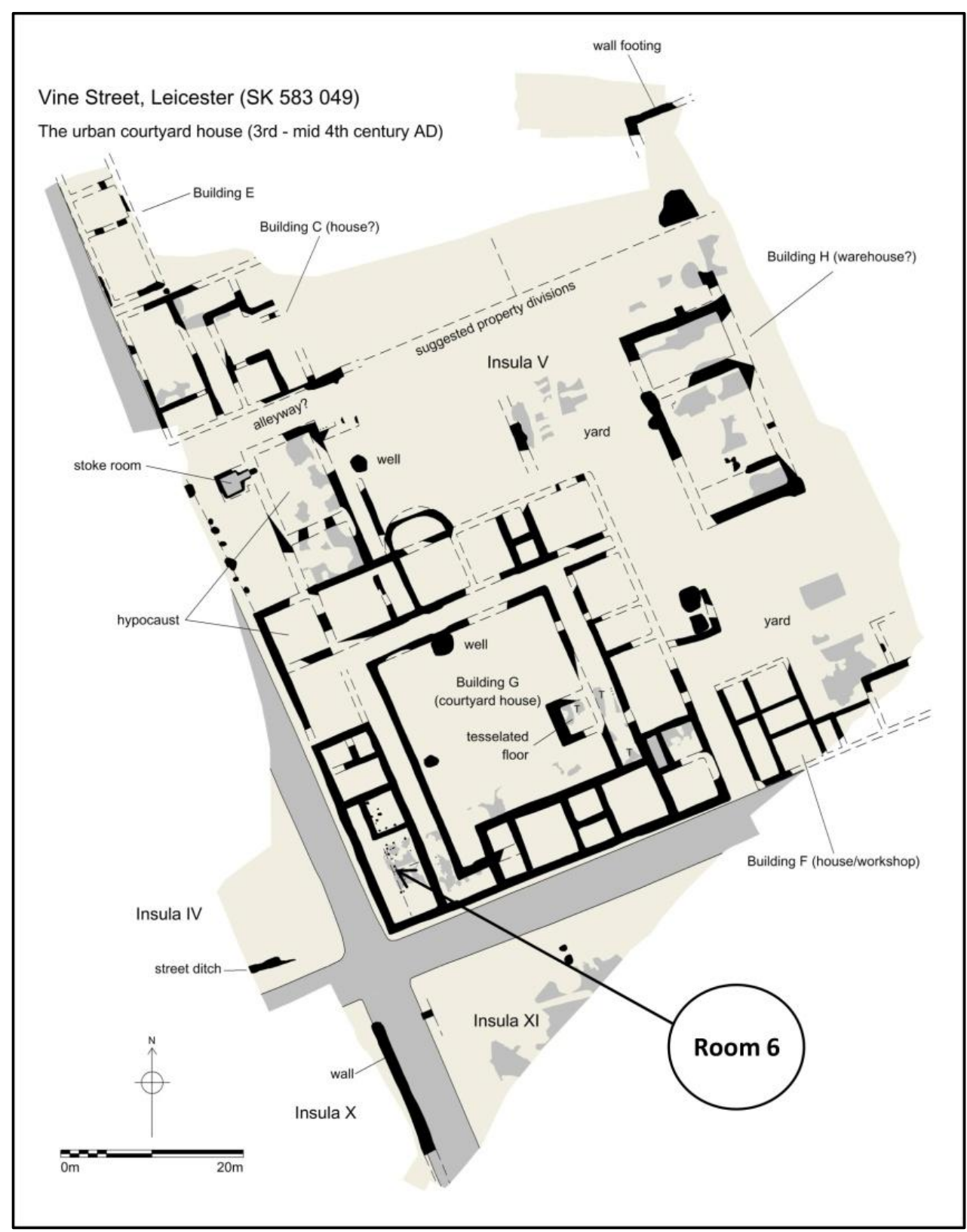


$\underline{\text { Tasker et al./Figure } 2}$
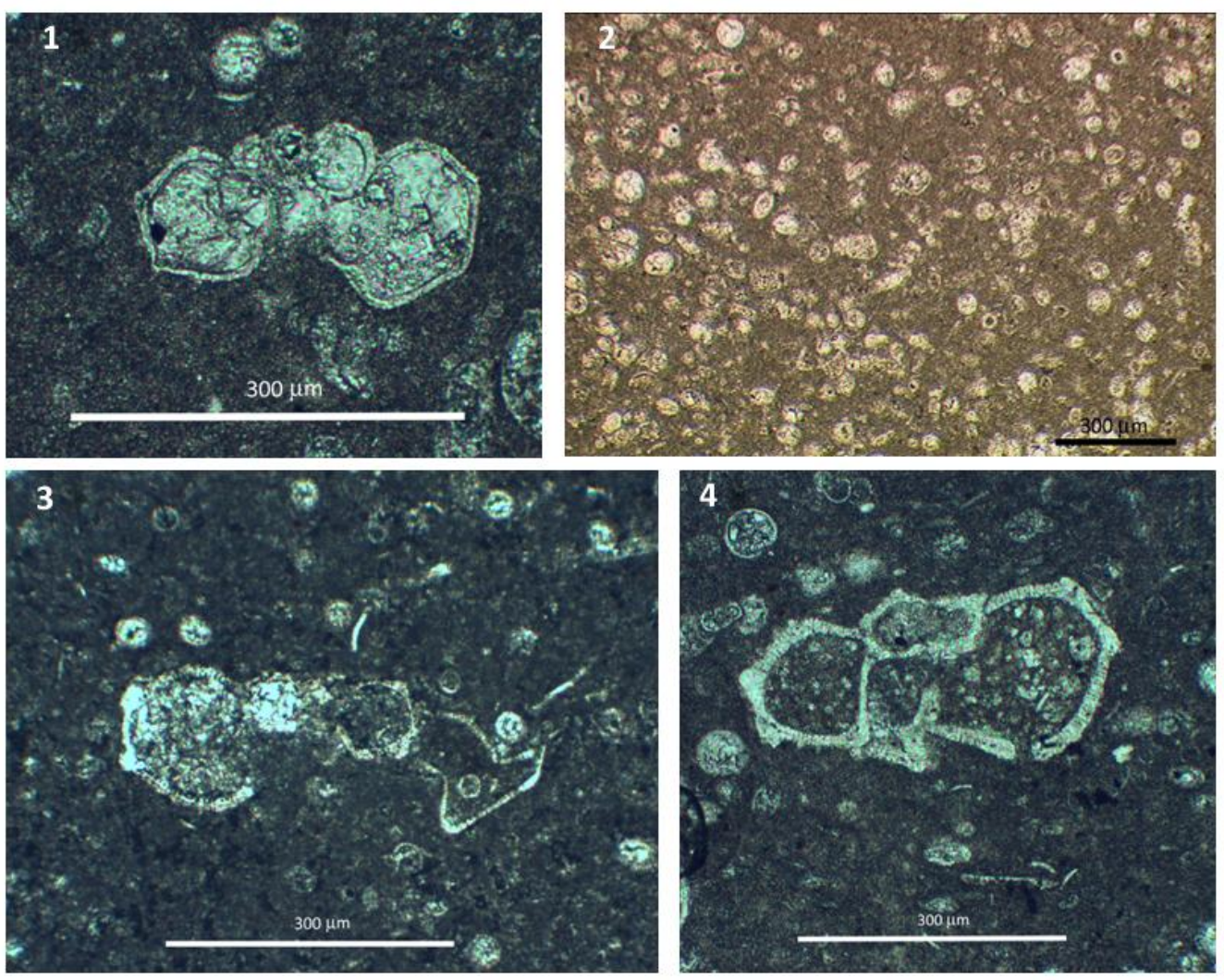
$\underline{\text { Tasker et al./Figure } 3}$

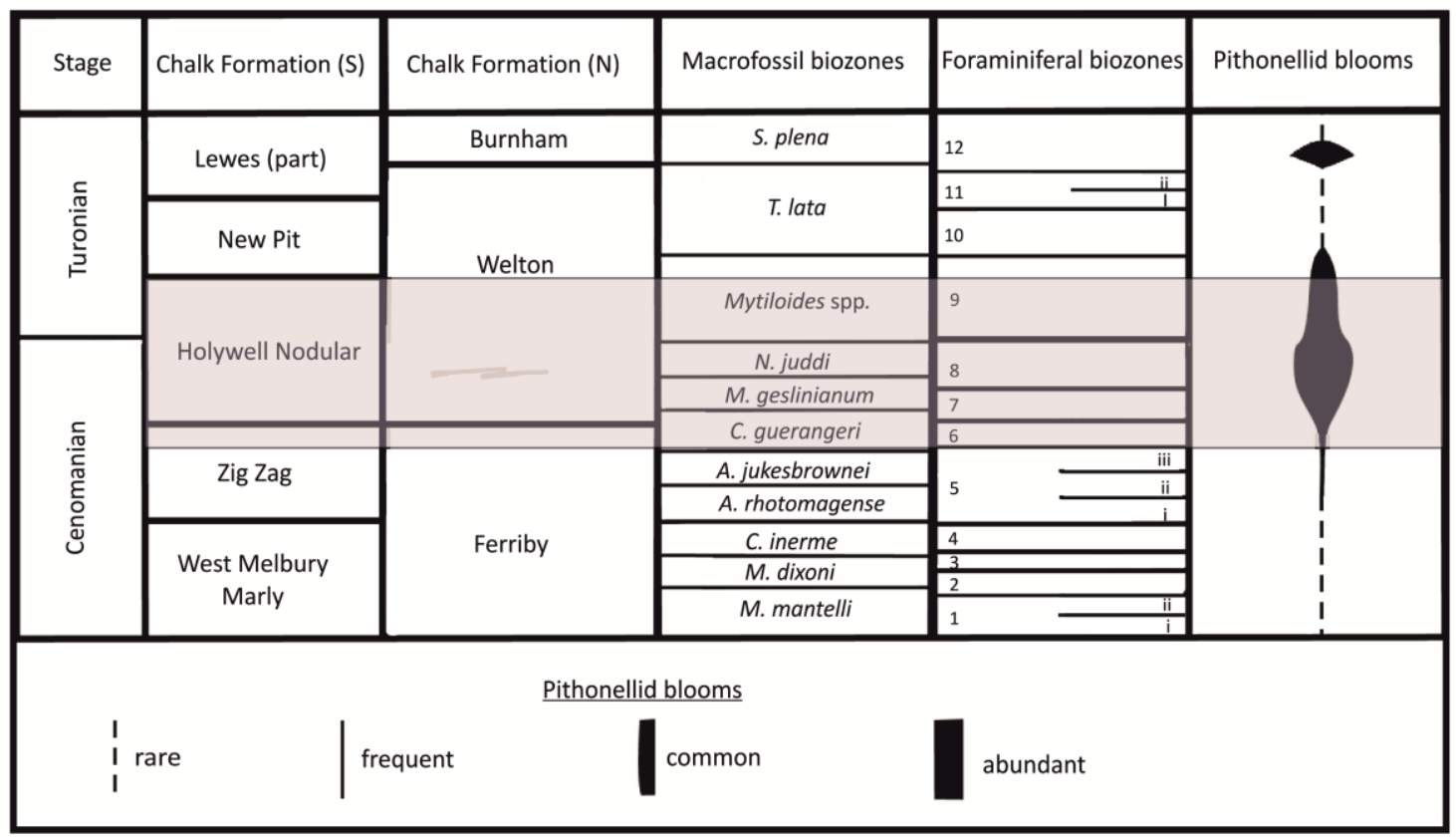


$\underline{\text { Tasker et al./ Figure } 4}$

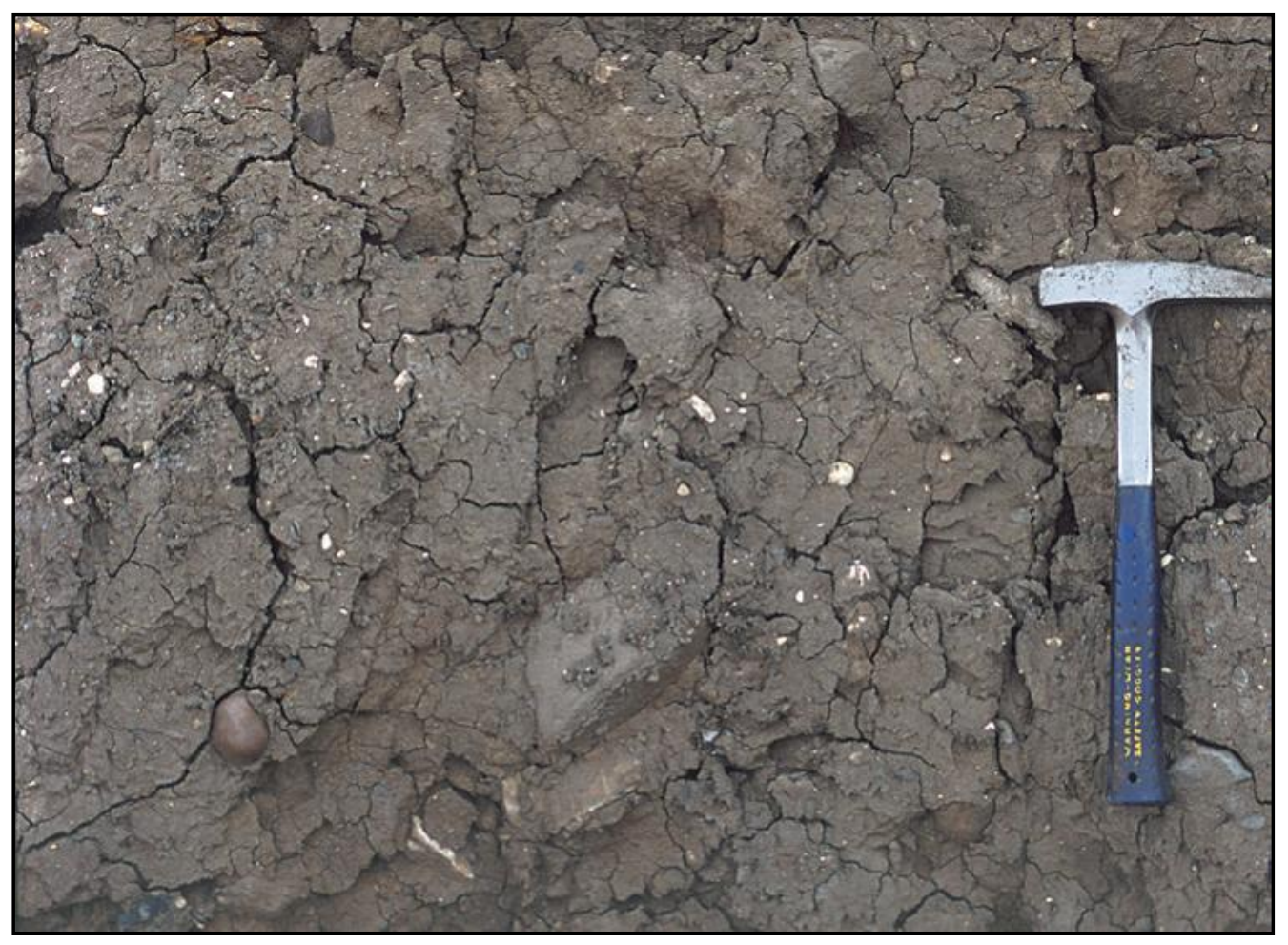


$\underline{\text { Tasker et al./Figure } 5}$

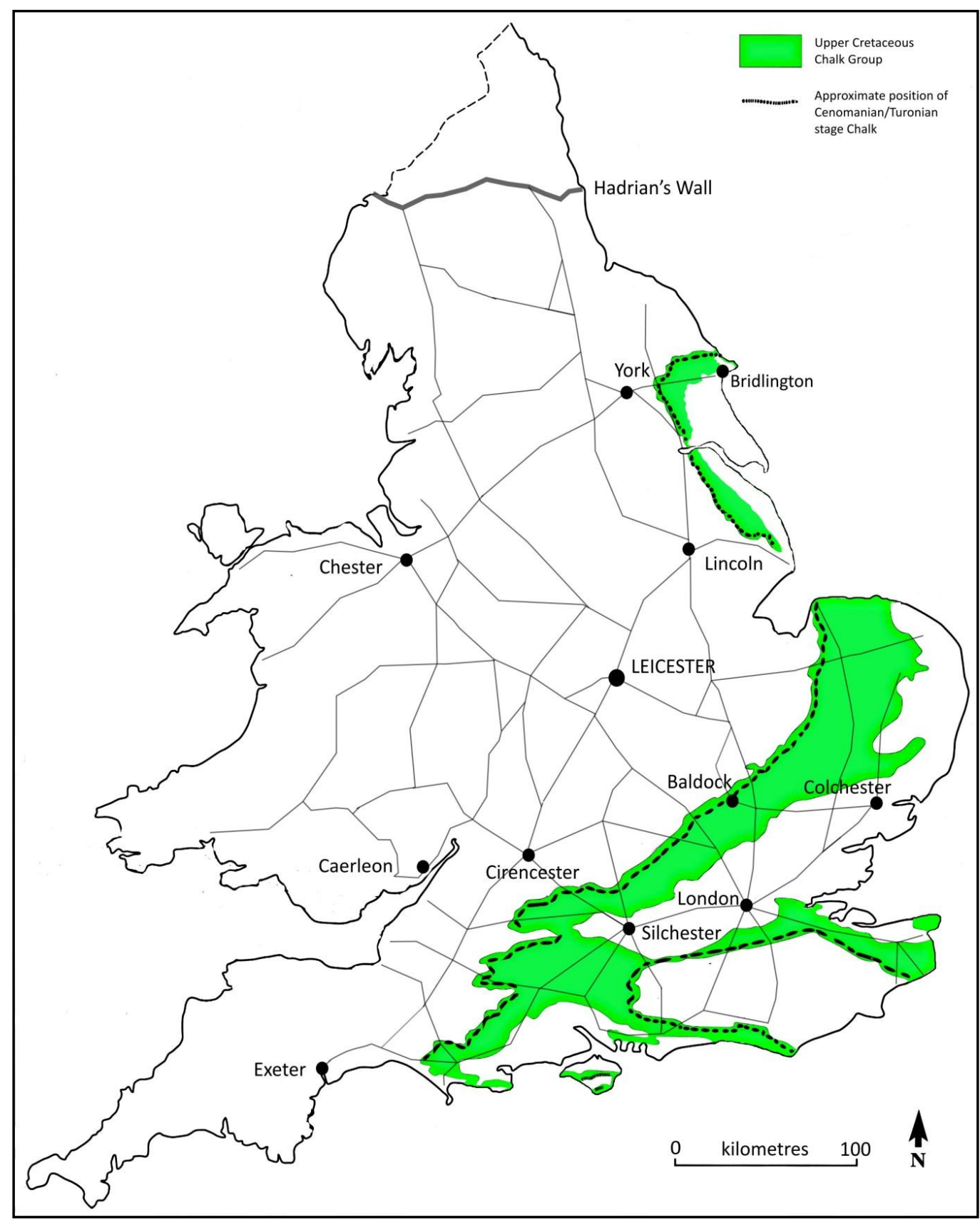




\section{$\underline{\text { TABLES }}$}

Table 1: Number of tesserae examined from each location in the Vine Street Town House, Leicester.

\begin{tabular}{|l|l|l|l|l|}
\hline \multirow{2}{*}{ LOCATION } & \multicolumn{2}{|l|}{ Tesserae } & Total \\
\cline { 2 - 5 } & Unprocessed & Processed & Thin sectioned & \\
\hline Vine Street A & 2 & 13 & 2 & 17 \\
\hline Vine Street B & 1 & 4 & 1 & 6 \\
\hline Vine Street C & - & 6 & 1 & 7 \\
\hline Vine Street D & - & - & 6 & 6 \\
\hline TOTAL & 3 & 23 & 10 & 36 \\
\hline
\end{tabular}


Tables 2-5: Microfossils found in tesserae from the Vine Street Town House excavation, Leicester

All tesserae were found in Room 6 of Building G of the Vine Street Town House, Leicester (SK583049).

\section{Table 2: Vine Street A}

\begin{tabular}{|c|c|c|c|}
\hline \multicolumn{4}{|c|}{$\begin{array}{l}\text { VINE STREET A } \\
\text { Tesserae dump, mid-late fourth century AD }\end{array}$} \\
\hline $\begin{array}{l}\text { Sample } \\
\text { number }\end{array}$ & $\begin{array}{l}\text { BGS (MPA) } \\
\text { number }\end{array}$ & $\begin{array}{l}\text { Archaeological } \\
\text { context number }\end{array}$ & Palaeontology \\
\hline LE_VS_A01 & MPA 62462 & A24.2003.5751.740 & $\begin{array}{l}\text { Heterohelix globulosa; Lenticulina rotula; Polymorphina } \\
\text { sp.; Praebulimina reussi. }\end{array}$ \\
\hline LE_VS_A02 & MPA 62463 & A24.2003 5751.740 & Hedbergella delrioensis; Heterohelix globulosa. \\
\hline LE_VS_A03 & MPA 62464 & A24.2003.5751.740 & Hedbergella delrioensis; Heterohelix globulosa. \\
\hline LE_VS_A04 & MPA 62465 & A24.2003.5751.740 & Pithonella sphaerica. \\
\hline LE_VS_A05 & MPA 62466 & A24.2003.5751.740 & $\begin{array}{l}\text { Hedbergella delrioensis; Heterohelix sp.; } \\
\text { Lingulogavelinella globosa. }\end{array}$ \\
\hline LE_VS_A06 & MPA 62467 & A24.2003.5751.740 & Heterohelix sp. \\
\hline LE_VS_A07* & MPA 62468 & A24.2003.5751.740 & $\begin{array}{l}\text { Pithonella ovalis. ?Frondicularia sp.; Hedbergella } \\
\text { brittonensis, H. delrioensis; Plectina cenomana; } \\
\text { Praebulimina sp. }\end{array}$ \\
\hline LE_VS_A08* & MPA 62469 & A24.2003.5751.740 & $\begin{array}{l}\text { Hedbergella brittonensis, H. planispira; } \\
\text { Praeglobotruncana helvetica. }\end{array}$ \\
\hline LE_VS_A09 & MPA 62470 & A24.2003.5751.740 & Pithonella sphaerica. \\
\hline LE_VS_A10 & MPA 62471 & A24.2003.5751.740 & Barren \\
\hline LE_VS_A11 & MPA 62472 & A24.2003.5751.740 & $\begin{array}{l}\text { Hedbergella brittonensis; Heterohelix sp.; Praebulimina } \\
\text { reussi. }\end{array}$ \\
\hline LE_VS_A12 & MPA 62473 & A24.2003.5751.740 & Barren \\
\hline LE_VS_A13 & MPA 62474 & A24.2003.5751.740 & Barren \\
\hline LE_VS_A14 & MPA 624775 & A24.2003.5751.740 & Pithonella sphaerica. \\
\hline LE_VS_A15 & MPA 62476 & A24.2003.5751.740 & Pithonella sphaerica. \\
\hline LE_VS_A16 & MPA 62477 & A24.2003.5751.740 & Pithonella sphaerica. \\
\hline LE_VS_A17 & MPA 62478 & A24.2003.5751.740 & Barren \\
\hline
\end{tabular}

*thin sections 


\begin{tabular}{|c|c|c|c|c|}
\hline \multicolumn{5}{|c|}{$\begin{array}{l}\text { VINE STREET B } \\
\text { Patched mortar floor, early-mid fourth century AD }\end{array}$} \\
\hline $\begin{array}{l}\text { Sample } \\
\text { number }\end{array}$ & $\begin{array}{l}\text { BGS (MPA) } \\
\text { number }\end{array}$ & $\begin{array}{l}\text { Archaeological } \\
\text { context number }\end{array}$ & Palaeontology & Comments \\
\hline LE_VS_B01 & MPA62479 & A24.2003.5886 & \multirow{5}{*}{$\begin{array}{l}\text { Few microfossils were } \\
\text { recovered and } \\
\text { identification of these } \\
\text { was not possible. A few } \\
\text { echinoid spines were } \\
\text { present. }\end{array}$} & \multirow{6}{*}{$\begin{array}{l}\text { All six tesserae smelled } \\
\text { strongly of bitumen when } \\
\text { crushed or thin sectioned. } \\
\text { The crushed tesserae material } \\
\text { was dirty grey in colour and } \\
\text { splintery in texture and was } \\
\text { identified as a calcareous } \\
\text { mudstone. }\end{array}$} \\
\hline LE_VS_B02 & MPA62480 & A24.2003.5886 & & \\
\hline LE_VS_B03 & MPA62481 & A24.2003.5886 & & \\
\hline LE_VS_B04 & MPA62482 & A24.2003.5886 & & \\
\hline LE_VS_B05 & MPA62483 & A24.2003.5886 & & \\
\hline LE_VS_B06* & MPA62484 & A24.2003.5886 & Barren & \\
\hline
\end{tabular}

* thin section

Table 4: Vine Street C

\begin{tabular}{|l|l|l|l|}
\hline \multicolumn{2}{|l|}{ VINE STREET C } \\
Tesserae dump, mid-late fourth century AD \\
\hline Sample & BGS (MPA) & Archaeological \\
number & number & Palaeontology \\
\hline LE_VS_C01 & MPA62485 & A24.2003.5266.626 & Barren \\
\hline LE_VS_C02 & MPA62486 & A24.2003.5266.626 & ?Gavelinella intermedia;?Gavelinella berthelini. \\
\hline LE_VS_C03 & MPA62487 & A24.2003.5266.626 & Barren \\
\hline LE_VS_C04 & MPA62488 & A24.2003.5266.626 & Barren \\
\hline LE_VS_C05 & MPA62489 & A24.2003.5266.626 & Barren \\
\hline LE_VS_C06 & MPA62490 & A24.2003.5266.626 & Barren \\
\hline LE_VS_C07* & MPA62491 & A24.2003.5266.626 & Pithonella sphaerica (abundant). Dicarinella canaliculata, \\
& & & $\begin{array}{l}\text { D. hagni, ?Epistomina sp.; Globigerinelloides cf } \\
\text { bentonensis; Hedbergella brittonensis, H. delrioensis; } \\
\end{array}$ \\
\hline
\end{tabular}

*thin section 


\section{Table 5: Vine Street D}

\begin{tabular}{|c|c|c|c|}
\hline \multicolumn{4}{|c|}{$\begin{array}{l}\text { VINE STREET D } \\
\text { Mosaic floor fragment (SF1084) }\end{array}$} \\
\hline $\begin{array}{l}\text { Sample } \\
\text { number }\end{array}$ & $\begin{array}{l}\text { BGS (MPA) } \\
\text { number }\end{array}$ & $\begin{array}{l}\text { Archaeological } \\
\text { context number }\end{array}$ & Palaeontology \\
\hline LE_VS_D01* & MPA62492 & A24.2003.5265.1084 & $\begin{array}{l}\text { Pithonella sphaerica. Hedbergella brittonensis; } H \text {. } \\
\text { delrioensis; Heterohelix sp.; Marginotruncana } \\
\text { marginata. }\end{array}$ \\
\hline LE_VS_D02* & MPA62493 & A24.2003.5265.1084 & Pithonella sphaerica (rare). Hedbergella sp. \\
\hline LE_VS_D03* & MPA62494 & A24.2003.5265.1084 & $\begin{array}{l}\text { Pithonella ovalis; P. sphaerica (flood proportions). } \\
\text { Hedbergella brittonensis; H. sp.; Heterohelix sp. Bivalve } \\
\text { prisms. }\end{array}$ \\
\hline LE_VS_D04* & MPA62495 & A24.2003.5265.1084 & $\begin{array}{l}\text { Pithonella sphaerica (common). Hedbergella } \\
\text { brittonensis; Heterohelix moremani; indeterminate } \\
\text { planktonic foraminifera. Bivalve fragment. }\end{array}$ \\
\hline LE_VS_D05* & MPA62496 & A24.2003.5265.1084 & $\begin{array}{l}\text { Pithonella ovalis; P. sphaerica; Hedbergella delrioensis; } \\
\text { H. sp.; Gavelinella sp. }\end{array}$ \\
\hline LE_VS_D06* & MPA62497 & A24.2003.5265.1084 & Barren of foraminifera. Bivalve fragments. \\
\hline
\end{tabular}

*thin sections 